\title{
Temporal Succession of Phytoplankton Assemblages in a Tidal Creek System of the Sundarbans Mangroves: An Integrated Approach
}

\author{
Dola Bhattacharjee, ${ }^{1,2}$ Brajogopal Samanta, ${ }^{1}$ \\ Anamitra Anurag Danda, ${ }^{3}$ and Punyasloke Bhadury ${ }^{1}$ \\ ${ }^{1}$ Integrative Taxonomy and Microbial Ecology Research Group, Department of Biological Sciences, Indian Institute of Science Education \\ and Research-Kolkata (IISER-K), Mohanpur Campus, Nadia, Mohanpur-741252, West Bengal, India \\ ${ }^{2}$ Ministry of Environment and Forests, Eastern Regional Office, Chandrasekharpur, Bhubaneswar-751023, Odisha, India \\ ${ }^{3}$ Sundarbans Programme and Climate Adaptation (Coastal Ecosystems), WWF-India, Jodhpur Park, \\ Kolkata-700068, West Bengal, India
}

Correspondence should be addressed to Punyasloke Bhadury; pbhadury@iiserkol.ac.in

Received 9 April 2013; Accepted 19 May 2013

Academic Editor: Rafael Riosmena-Rodríguez

Copyright (C) 2013 Dola Bhattacharjee et al. This is an open access article distributed under the Creative Commons Attribution License, which permits unrestricted use, distribution, and reproduction in any medium, provided the original work is properly cited.

\begin{abstract}
Sundarbans, the world's largest mangrove ecosystem, is unique and biologically diverse. A study was undertaken to track temporal succession of phytoplankton assemblages at the generic level $(\geq 10 \mu \mathrm{m})$ encompassing 31 weeks of sampling (June 2010-May 2011) in Sundarbans based on microscopy and hydrological measurements. As part of this study, amplification and sequencing of type ID $r b c \mathrm{~L}$ subunit of RuBisCO enzyme were also applied to infer chromophytic algal groups $(\leq 10 \mu \mathrm{m}$ size) from one of the study points. We report the presence of 43 genera of Bacillariophyta, in addition to other phytoplankton groups, based on microscopy. Phytoplankton cell abundance, which was highest in winter and spring, ranged between 300 and 27,500 cells/L during this study. Cell biovolume varied between winter of $2010\left(90-35281.04 \mu \mathrm{m}^{3}\right)$ and spring-summer of $2011\left(52-33962.24 \mu \mathrm{m}^{3}\right)$. Winter supported large chain forming diatoms, while spring supported small sized diatoms, followed by other algal groups in summer. The clone library approach showed dominance of Bacillariophyta-like sequences, in addition to Cryptophyta-, Haptophyta-, Pelagophyta-, and Eustigmatophyta-like sequences which were detected for the first time highlighting their importance in mangrove ecosystem. This study clearly shows that a combination of microscopy and molecular tools can improve understanding of phytoplankton assemblages in mangrove environments.
\end{abstract}

\section{Introduction}

The most implicit elements of the global carbon cycle are those involving the coastal environments that embrace a great variety of habitats including mangroves which are located in tropical and subtropical regions of the world. These ecosystems are known to account for $14-30 \%$ of the marine primary production [1] and annual sequestration of approximately 22.8 million metric tons of carbon [2]. Phytoplankton forms the basis of the aquatic primary production in mangrove environments. These photosynthetic organisms are major contributors of high fish productivity in mangrove habitats [3].

Approximately $41 \%$ of the world's mangrove occurs in South and Southeast Asia, out of which Indonesia alone accounts for $23 \%$ [4]. Sundarbans $\left(21^{\circ} 32^{\prime}\right.$ and $22^{\circ} 40^{\prime} \mathrm{N}$; $88^{\circ} 05^{\prime}$ and $89^{\circ} \mathrm{E}$ ), world's largest contiguous deltaic mangrove ecosystem located at the apex of Bay of Bengal, encompasses over 102 islands with a network of innumerable rivers, rivulets, and creeks. This vast deltaic region is formed at the estuarine phase of the Ganges-Brahmaputra and Meghna river system across India and Bangladesh covering a total area 
of approximately $10,000 \mathrm{~km}^{2}$ and tidally influenced by coastal water from the Bay of Bengal.

Phytoplankton assemblages in the Sundarbans are usually dominated by diatoms and this phytoplankton group is a major contributor of primary productivity in the region. More than 76 species of diatoms have been reported from this ecoregion [5]. Centric diatoms, including the genus Coscinodiscus, usually dominates the assemblage in Sundarbans $[6,7]$. However, almost all the studies have used plankton nets of higher mesh sizes ( $20 \mu \mathrm{m}$ mesh and higher) to study the phytoplankton assemblages and therefore these studies did not capture the dynamics of phytoplankton size class of lesser than $20 \mu \mathrm{m}$ in Sundarbans $[7,8]$. Hence, there is lack of information on the composition and role of different size class of phytoplankton in Sundarbans which warrant further investigation.

In the past, studies on natural phytoplankton assemblages from the Sundarbans have employed conventional approaches like microscopy and photosynthetic pigment analysis [6,9]. However, recent molecular techniques can provide improved insights into phytoplankton diversity from this ecologically important environment similar to other studies $[10,11]$. Key functional genes involved in carbon metabolism may provide clues to the important functions in carbon biogeochemistry that phytoplankton perform present another possibility to illustrate the diversity of phytoplankton. In the marine environment, photosynthetic fixation of carbon in phytoplankton is mainly catalyzed by the enzyme RuBisCO [12]. Several forms of RuBisCO can be distinguished on the basis of subunit assembly and biochemical characteristics [13]. The sequence of the $r b c \mathrm{~L}$ gene encoding the large subunit of enzyme is conserved and can be used for taxonomic distinction in phytoplankton. Studies on the molecular diversity and community structure of natural phytoplankton assemblages across different oceanographic realms have increased our understanding of phytoplankton ecology and dynamics based on the rbcL amplification and sequencing approach [14-16]. However, molecular techniques have not been applied so far towards elucidating the phytoplankton communities from any mangrove ecosystem including Sundarbans.

The main objective of this study was to understand how natural phytoplankton fractions ( $\geq 10 \mu \mathrm{m}$ size class) from the world's largest contiguous tropical mangrove ecosystem (Sundarbans) undergo generic shifts along temporal scales in link with hydrological parameters. In addition, for the first time in a tropical mangrove setting, molecular techniques based on the amplification and sequencing of the chromophytic algal type ID $r b c \mathrm{~L}$ subunit encoding the RuBisCO enzyme was applied to study phytoplankton assemblages of smaller size fractions $(\leq 10 \mu \mathrm{m})$ from Sundarbans.

\section{Materials and Methods}

2.1. Study Area. The study was undertaken for 31 weeks across two predefined sampling stations (referred to as Stn1 and Stn 2 with GPS coordinates in Figure 1) in Chemaguri creek located in Sagar Island of the Sundarbans. The creek

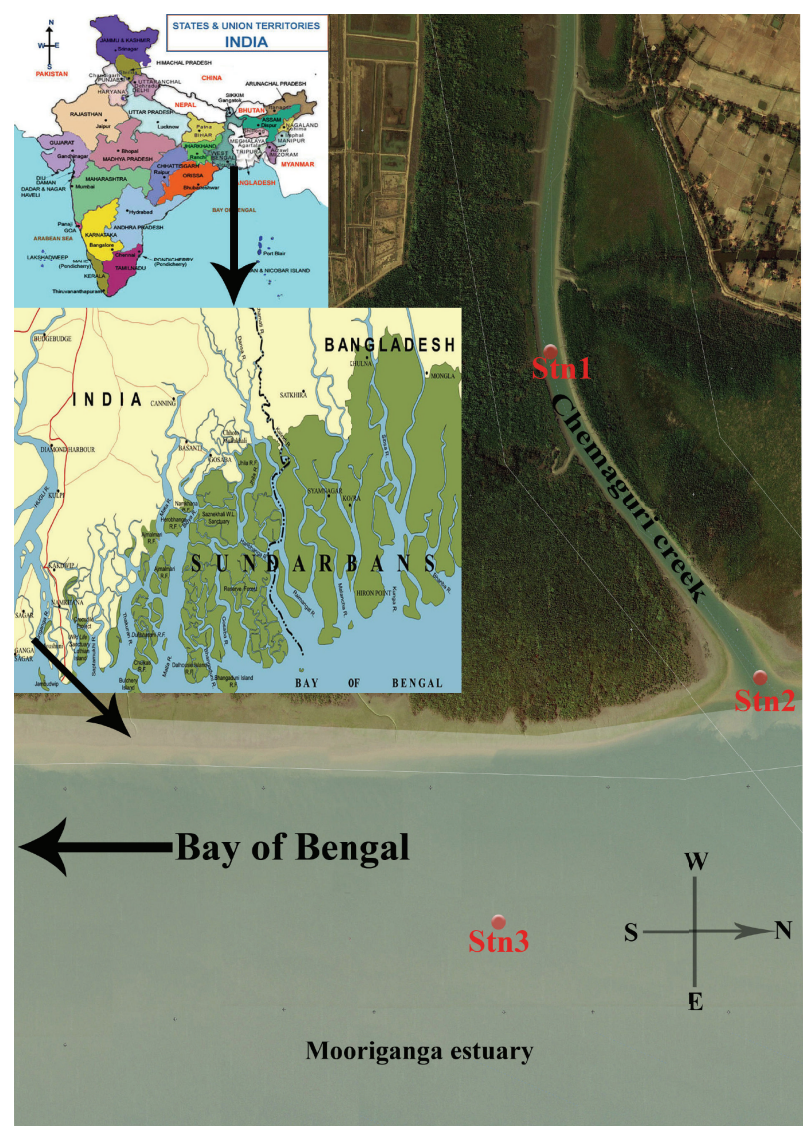

Figure 1: Map of the study area. Stn1, Stn2, and Stn3 are the sampling stations whose geographical locations are as follows: Stn1 $\left(\mathrm{N} 21^{\circ} 40^{\prime} 44.4^{\prime \prime} \mathrm{E} 88^{\circ} 08^{\prime} 49.5^{\prime \prime}\right)$ and Stn2 (N21 40 $\left.59.3^{\prime \prime} \mathrm{E} 88^{\circ} 09^{\prime} 13.1^{\prime \prime}\right)$ in Chemaguri creek; Stn3 (N21 40 $40.6^{\prime \prime}$ E88 $09^{\prime} 19.2^{\prime \prime}$ ) in Mooriganga estuary.

is shallow in nature and strongly influenced by tidal waters influx from the coastal Bay of Bengal. The Stnl is located upstream of the creek while Stn2 is next to the mouth of the creek facing the Mooriganga estuary. Occasional samplings were also undertaken in another station (Stn3) located in the adjoining Mooriganga estuary (as detailed in Figure 1 with GPS coordinates). The study area is located in the southwestern part of the Sundarbans, around $107 \mathrm{Km}$ from Kolkata city in West Bengal, India.

The Sagar Island, the largest tide-dominated island (tidal ranges around $4.6 \mathrm{~m}$ ) of Sundarbans, is only $6.5 \mathrm{~m}$ above sea level [17]. The island has some mangrove patches and is surrounded by the river Hooghly in the north and its west, Mooriganga in the eastern side, while the southern part faces the coastal Bay of Bengal. Aquaculture is extensively practiced by the local inhabitants of the Sagar Island and a number of shrimp farms are located within close vicinity of the Chemaguri creek [9].

2.2. Sampling. From June 2010 to May 2011 ( 1 to 31 weeks), surface water samples were collected from each station, once per week from the study sites (Table 1). For the months from 
TABLE 1: Month-wise distribution of sampling weeks across the study period (2010-2011).

\begin{tabular}{lcc}
\hline Months & Sampling weeks & Seasons \\
\hline June 2010 & 1 & Summer \\
July 2010 & $2-4$ & Summer \\
August 2010 & $5-6$ & Monsoon \\
September 2010 & $7-10$ & Monsoon \\
October 2010 & $11-12$ & Monsoon \\
November 2010 & $13-15$ & Post-monsoon \\
December 2010 & $16-19$ & Winter \\
February 2011 & $20-21$ & Winter \\
March 2011 & $22-26$ & Spring \\
April 2011 & $27-28$ & Spring \\
May 2011 & $29-31$ & Summer \\
\hline
\end{tabular}

June to November (2010) and April to May (2011) sampling was not possible for all the weeks because of cyclone alerts in the study area. Similarly, sampling could not be undertaken in January (2011) due to inaccessibility of sampling sites because of "Ganga-Sagar" event.

\subsection{Phytoplankton Collection and Taxonomic Enumeration.} Fifty litres of surface water was passed through a phytoplankton net $(10 \mu \mathrm{m}$ mesh size) and the concentrated biomass was subsequently preserved in neutral formalin (4\%) solution immediately following collection. In the laboratory, preserved water samples were further concentrated for phytoplankton by gravity sedimentation $(24 \mathrm{~h})$ and subsequently enumerated based on drop count method under a brightfield microscope (Magnus, MLX-Bi) [18]. Microscopy based identifications were done following standard keys [19-21]. Photographic documentation (Carl Ziess, LSM710-AXIOOBSERVER version Z.1; bright field and DIC images) of dominant phytoplankton taxa $(10 \mu \mathrm{m}$ size class and above) from the study sites was also undertaken as part of this study.

Cell dimensions of the numerically dominant diatom taxa (Coscinodiscus, Chaetoceros, Cyclotella, Thalassiosira, Navicula, and Nitzschia) in winter (19th-21st week) and spring-summer (23rd-31st week) collections of phytoplankton were measured with a micro-meter (ERMA, Japan) and cell volumes (biovolume) were calculated by geometric approximations based on published methodology [22].

2.4. Measurement of Hydrological Parameters. Hydrological parameters, namely, salinity, surface water temperature (SWT), pH, and Secchi depth, were recorded using refractometer (Erma, Japan), digital thermometer (Eurolab ST9269B), pH meter (Eco testr), and a Secchi disc, respectively, at time of sampling in each station.

\subsection{Analysis of Nitrate, (Ortho)-Phosphate and Silicate Con-} centration in Water. Precleaned amber bottles $(125 \mathrm{~mL})$ were used for collecting water samples from the stations, immediately fixed in $1 \%$ neutral formalin based on established protocol [23], since the sampling sites were remote locationwise and subsequently transported to the laboratory for nutrient analyses. Dissolved nitrate was measured in situ in a UV-Vis spectrophotometer (Beckman Coulter, DU730) based on published protocol [24] while dissolved (ortho)phosphate was determined in the same spectrophotometer based on acid-molybdate method [25]. Silicate concentration was measured in spectrophotometer based on published protocol of ammonium molybdate chemistry [26].

2.6. Photosynthetic Pigment Analysis. For photosynthetic pigment analysis, $1 \mathrm{~L}$ of surface water sample was collected separately in dark bottles from each station, filtered onto $0.45 \mu \mathrm{m}$ cellulose nitrate membrane filters (Rankem), and extracted overnight in $90 \%$ acetone at $4^{\circ} \mathrm{C}$ in the dark. Pigment extracts for chlorophyll- $a$ and fucoxanthin were centrifuged and subsequently quantified in a UV-Vis spectrophotometer (Shimadzu, UV1800) based on published protocol [27].

2.7. Genomic DNA Extraction. Surface water samples were collected from Stn2 of the creek in early summer (6th April, 2010 as part of a preliminary study), winter (27th December 2010, 19th week), and spring (17th March 2011, 24th week) for studying the natural phytoplankton assemblage patterns based on molecular approach. At the time of sampling, biomass from surface water (50 litres) was initially concentrated down to $1 \mathrm{~L}$ volume using a phytoplankton net $(10 \mu \mathrm{m}$ mesh size) and an additional $1 \mathrm{~L}$ of Stn2 surface water (not passed through the phytoplankton net) was mixed with the concentrated volume to make a final volume of $2 \mathrm{~L}$. The $2 \mathrm{~L}$ sample was subsequently filtered through $0.22 \mu \mathrm{m}$ sterivex filter (Millipore) using a peristaltic pump. The filters were stored at $-20^{\circ} \mathrm{C}$ until DNA extraction. Genomic DNA was extracted from the sterivex filters following standard protocol [28].

2.8. rbcL Gene Fragment Amplification and Clone Library. Type ID $r b c L$ gene fragment was amplified from environmental DNA isolated from sterivex filters for the months of April and December (2010) as well as March 2011 (Stn2). Previously published PCR primers were used to amplify $554 \mathrm{bp}$ rbcL fragments in this study [29]. Each PCR reaction consisted of $0.5 \mu \mathrm{L}(\sim 20 \mathrm{ng})$ DNA template, $5.0 \mu \mathrm{L} 10 \mathrm{X}$ Taq buffer, $5 \mu \mathrm{L}$ dNTP (final concentration $0.2 \mathrm{mM}$ ), $4 \mu \mathrm{L}$ $\mathrm{MgCl}_{2}$ (final concentration $2.0 \mathrm{mM}$ ), $0.5 \mu \mathrm{L}$ each primer (final concentration $5 \mu \mathrm{M}), 1 \mu \mathrm{L}$ BSA $(1 \mathrm{mg} / \mathrm{mL}), 0.5 \mu \mathrm{L}$ DNA Taq polymerase $(5 \mathrm{U} / \mu \mathrm{L})$ [MP Biomedical Asia], and water to make a final volume of $50 \mu \mathrm{L}$. PCR conditions were as follows: initial denaturation at $95^{\circ} \mathrm{C}$ for $10 \mathrm{~min}, 35$ cycles of $95^{\circ} \mathrm{C}$ for $1 \mathrm{~min}, 52^{\circ} \mathrm{C}$ for $1 \mathrm{~min}, 72^{\circ} \mathrm{C}$ for $1 \mathrm{~min}$, and final extension at $72^{\circ} \mathrm{C}$ for $20 \mathrm{~min}$. PCR reactions for each environmental DNA sample were performed in triplicates, pooled together, and subsequently purified using Qiagen Gel Purification Kit (Qiagen) as per manufacturer's instruction.

2.9. Clone Library and DNA Sequencing. Purified PCR products were cloned using pGEM-T Easy vector system (Promega) following manufacturer's instructions. Plasmid DNA containing the inserts was sequenced with SP6 primer in an ABI 3130 Genetic Analyzer. 
2.10. Sequence Analysis and Molecular Phylogeny. Chromatograms were checked in BioEdit v7.0 for any ambiguity or error before downstream analyses. The generated DNA sequences were translated into amino acid sequences using Transeq (http://www.ebi.ac.uk/emboss/transeq) and subsequently compared with published $r b c \mathrm{~L}$ sequences from GenBank, EMBL, DDBJ, and PDB using blastp tool (http://blast.ncbi.nlm.nih.gov/Blast.cgi). Uncultured environmental $r b c \mathrm{~L}$ and cultured phytoplankton $r b c \mathrm{~L}$ amino acid sequences that overlapped with the sequences generated from this study based on blastp validation [only top ten blastp hits were included] were aligned using web version of ClustalX (http://www.ebi.ac.uk/Tools/msa/clustalw2/). The alignment consisted of $52 \mathrm{rbcL}$ clones generated from this study and 114 published cultured phytoplankton and uncultured photosynthetic eukaryotic $r b c \mathrm{~L}$ sequences from the databases. The alignment file was manually checked in Seaview v4.0. Phylogenetic tree was constructed using Neighbor-joining method in MEGA version 5 [30, 31]. Bootstrap test (1000 replicates) was conducted to get the best topology of consensus tree with the value $>50 \%$ significant branching [32]. The sequences generated from this study have been submitted to GenBank and their accession numbers are from KF035830-KF035881.

2.11. Statistical Analysis. To compare microscopic data with $r b c \mathrm{~L}$ clone library data, 52 sequences generated from this study were grouped into operational taxonomic units (OTUs, phylotypes) based on 3\% cut off at the amino acid level using the program DOTUR [33]. Shannon-Wiener indices were calculated for the measurement of biodiversity from the pooled $r b c \mathrm{~L}$ clone library as well as from individual clone library representing three time points of Stn2. Total expected number of OTUs in each clone library was calculated using nonparametric richness estimator ChaoI. Phylotype (or OTUs) frequency curve was prepared to determine the OTUs frequency across the clone libraries. Rarefaction analysis was undertaken to compare the diversity of $r b c \mathrm{~L}$ clone libraries.

\section{Results}

3.1. Hydrological Parameters. Hydrological parameters such as surface water temperature (SWT), salinity, $\mathrm{pH}$, and Secchi depth were recorded from all the stations during the entire study period (Figures 2(a)-2(d)). Mean values for SWT, $\mathrm{pH}$, salinity, and secchi depth detected inside the creek were $28.8^{\circ} \mathrm{C}, 8.11,7.7 \mathrm{ppt}$, and $23.16 \mathrm{~cm}$, respectively. The mean values for SWT, pH, salinity, and Secchi depth from the estuarine station $(\mathrm{Stn} 3)$ were $28.8^{\circ} \mathrm{C}, 8.07,10 \mathrm{ppt}$, and $28.02 \mathrm{~cm}$ respectively.

In the creek system, highest salinity values were recorded from Stn2 (mean, $7.9 \mathrm{ppt}$ ), while at station Stn1 the salinity was relatively low (mean, $7.45 \mathrm{ppt}$ ). The $\mathrm{pH}$ values were rather consistent for both stations during the study period (8.1 on an average). Secchi depth values were highest in Stn1 for almost all the season except in some sampling weeks (mean $24.3 \mathrm{~cm}$ ). Stnl showed comparatively higher mean SWT $\left(28.9^{\circ} \mathrm{C}\right)$ against Stn2 (mean SWT, 28.7 $\left.{ }^{\circ} \mathrm{C}\right)$.

3.2. Phytoplankton Abundance ( $\geq 10 \mu \mathrm{m}$ Size Class) in the Creek and Adjoining Estuarine Stations. In the creek, the abundance of phytoplankton ( $\geq 10 \mu \mathrm{m}$ size class and above) was highest in Stn1 (mean, $5.3 \times 10^{3}$ cells/L), lowest in Stn2 (mean, $4 \times 10^{3}$ cells $/ \mathrm{L}$ ), while it was around $4.7 \times 10^{3}$ cells $/ \mathrm{L}$ (mean) in the estuarine station (Stn3) for the study period. However, the variation in mean phytoplankton abundance was not found to be significant. An increase in phytoplankton abundance was observed across all the stations (in creek and estuary) during winter encompassing 16th-19th week of sampling (December 2010) (Figure 3). Winter also displayed high phytoplankton generic diversity across the study area.

Phytoplankton abundance was lowest across all the stations from monsoon to post-monsoon encompassing 11th15th weeks of sampling (October-November, 2010) (mean, Stn $1=1.15 \times 10^{3}$ cells $/ \mathrm{L} ; \operatorname{Stn} 2=4.4 \times 10^{2}$ cells $/ \mathrm{L}$ and Stn3 $31.4 \times 10^{3}$ cells $/ \mathrm{L}$ ) (Figure 3 ). On the $23 \mathrm{rd}-24 \mathrm{th}$ week of sampling (spring, March 2011) notable peaks in phytoplankton abundance were recorded across the stations (mean, Stn $1=7.7 \times 10^{3}$ cells $/ \mathrm{L} ; \operatorname{Stn} 2=6.1 \times 10^{2}$ cells $/ \mathrm{L}$ and Stn3 $=3.9 \times 10^{3}$ cells $/ \mathrm{L}$ ) with overall low generic diversity (Figure 3).

3.3. Phytoplankton Assemblages ( $\geq 10 \mu \mathrm{m}$ Size Class) in the Creek and Adjoining Estuarine Stations. A total of 52 genera of phytoplankton ( $\geq 10 \mu \mathrm{m}$ size class) were documented based on microscopy in the present study. In Stn1 and Stn2, 51 and 49 genera were detected, respectively, whereas 47 genera of phytoplankton were identified from Stn3. Presence/absence of phytoplankton genera across all the three stations has been detailed in Table S1 ( see Supplementary Material available online at http://dx.doi.org/10.1155/2013/824543). Diatoms consisting of centric and pennate forms with varying sizes $(\geq 10 \mu \mathrm{m})$ represented bulk of the assemblages during the study period. In Stn1 and Stn2, 39 and 37 genera of diatoms, respectively, were detected in phytoplankton assemblages, whereas in Stn3 detected diatom genera number was 36. Centric diatom genera in Stn1 and Stn2 were represented by 20 and 19 genera, respectively, whereas for Stn3 it was 18 genera for the entire study period. On the contrary, 19 and 18 pennate genera were detected from Stn1 and Stn2, respectively, and 18 genera from Stn3 in this study. The araphid diatom genus, Thalassionema, was detected from all the stations during the course of this study. Centric diatom genera like Coscinodiscus, Chaetoceros, Thalassiosira and Cyclotella and pennate diatom genera like Navicula, Nitzschia, Pleurosigma, and Thalassionema dominated in almost every sample from Stn1 and Stn 2 over the study period. In Stn3, centric diatom genera like Thalassiosira, Coscinodiscus, and Melosira whereas pennate diatom genera like Navicula, Nitzschia, and Pleurosigma dominated in almost all the samples throughout the study period. Dominant summer (June-July, 2010; 1st-4th week) diatom assemblages consisted of genera like Coscinodiscus, Odontella, and Cyclotella, while the monsoon (August-October, 


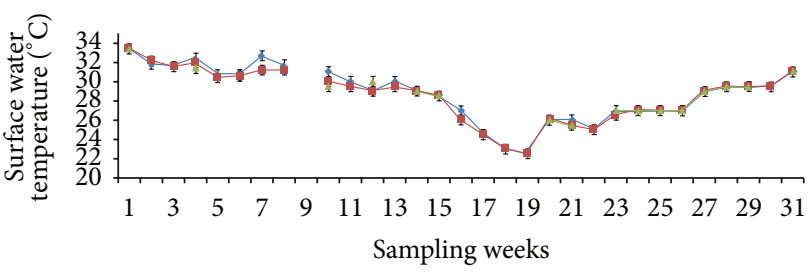

(a)

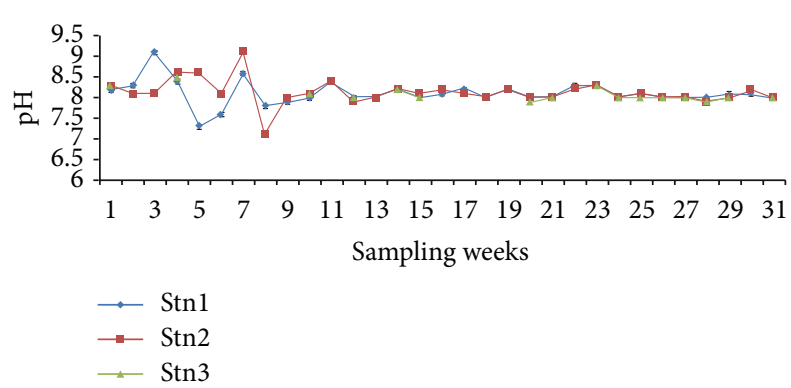

(c)

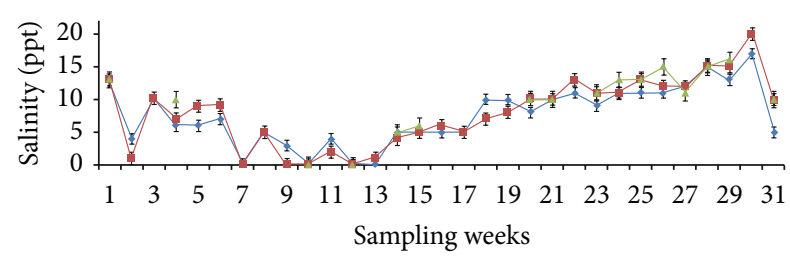

(b)

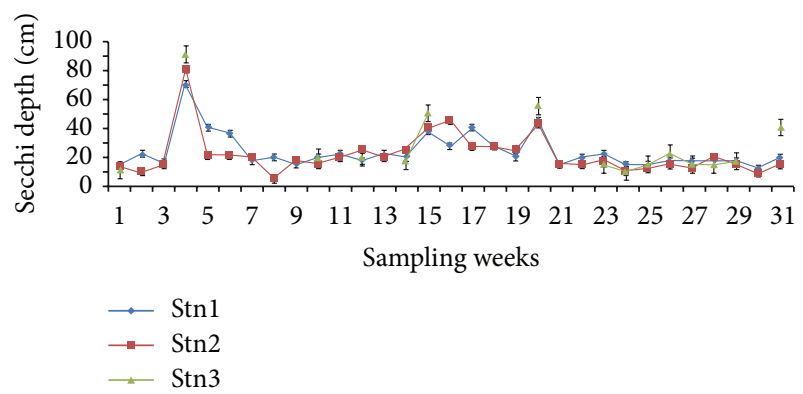

(d)

Figure 2: Physicochemical parameters prevailed across the stations; (a) SWT $\left({ }^{\circ} \mathrm{C}\right),(\mathrm{b})$ salinity (ppt), (c) pH, and (d) Secchi depth (cm) profiles.

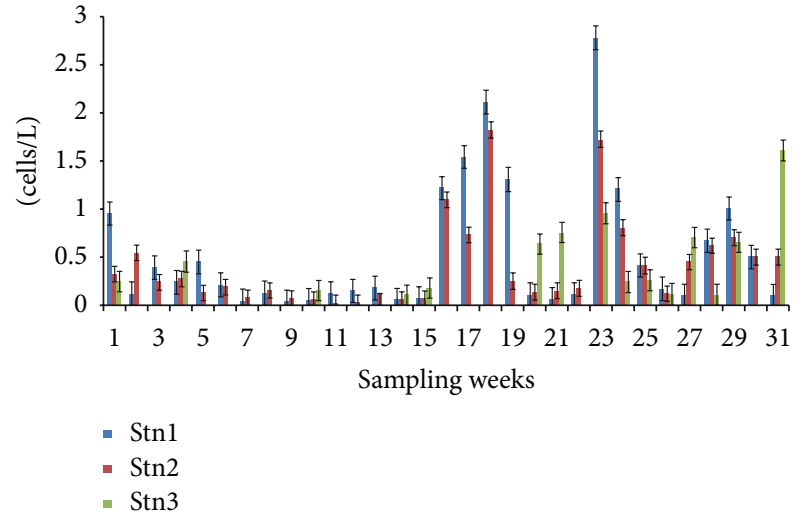

Figure 3: Abundance of phytoplankton cells (10 $\mu \mathrm{m}$ size and above) across the study period in Chemaguri creek and Mooriganga estuarine system.

2010; 5th-12th week) diatom assemblage was dominated by genera belonging to Skeletonema, Cyclotella, Coscinodiscus, Thalassiosira, and Gyrosigma across all the stations. Many of the diatom genera such as Actinocyclus, Bacteriastrum, Cerataulina, Eucampia, Planktoniella, Bacillaria and Cocconeis were documented from all the stations in winter (16th21st week). In the spring of 2011 (22nd-28th week), diatom genera like Triceratium, Asterionella, Climacosphenia and Fragilaria appeared in the study area (documented from all the stations). Genera like Amphora, Cymbella, Surirella, and Sellaphora were abundant in summer (29th-31st week) from the study area. Certain diatom genera showed restricted spatial distribution patterns. For example, Amphipleura (3rd week and 25th week), Hemidiscus (16th and 18th week), and
Paralia (23rd week) were recorded only from Stn1, while Minutocellus (31st week) was detected only from Stn2 (Table 2). In Stn3, the diatom genus Eucampia was detected in 21st week of the study period.

Dinophyta, represented by 5 genera with varying sizes, namely, Ceratium, Peridinium, Dinophysis, Protoperidinium and Noctiluca, were also documented. Like diatoms, dinophytes displayed temporal "appearance-disappearance" pattern throughout the seasons. For example, the genus Dinophysis was documented in summer (1st-4th week) whereas Noctiluca were abundant only during winter (20th-21st week) across all the stations. Genera like Ceratium and Peridinium showed year round presence with high abundance in summer across all the stations.

We have also recorded the presence of an unidentified member of Cryptophyta in water samples collected during summer of 2011 (31st week) from the creek stations.

Cyanophyta, represented by 6 genera, namely, Oscillatoria, Phormidium, Raphidiopsis, Lyngbya, Synechococcus, and Anabaena were documented from the Chemaguri creek and adjoining Mooriganga estuary stations. Abundance of Oscillatoria was noted in the 5th week of sampling and again during 26th-28th sampling weeks. Genera like Phormidium was in abundance in spring samples of 2011 (MarchApril), while taxa such as Lyngbya and Raphidiopsis were documented infrequently, usually in low abundance from the creek.

Non-diatom groups were found to constitute a substantial part of the phytoplankton assemblages $(\geq 10 \mu \mathrm{m}$ size class and above), in addition to diatoms over the study area (all the stations) from 1st to 15 th week of the study period. Subsequently (11th-16th week), diatoms represented bulk (100\%) of the assemblages across all stations with the sudden disappearance of non-diatom groups. Non-diatom groups 
TABLE 2: Weekly distributions of unique phytoplankton genera across the stations; genera with bold indicates these were detected during certain times of the study period.

\begin{tabular}{|c|c|c|c|}
\hline Weeks & Stn1 & Stn2 & Stn3 \\
\hline 1 & $\begin{array}{l}\text { Dinophysis, } \\
\text { Amphora, } \\
\text { Nitzschia }\end{array}$ & $\begin{array}{l}\text { Rhizosolenia, } \\
\text { Peridinium }\end{array}$ & $\begin{array}{c}\text { Thalassionema, } \\
\text { Melosira }\end{array}$ \\
\hline 2 & $\begin{array}{c}\text { Cymbella, } \\
\text { Chaetoceros }\end{array}$ & $\begin{array}{l}\text { Ceratium, } \\
\text { Nitzschia }\end{array}$ & - \\
\hline 3 & $\begin{array}{c}\text { Navicula, } \\
\text { Ceratium, } \\
\text { Chaetoceros, } \\
\text { Melosira, } \\
\text { Bellerochea, } \\
\text { Amphipleura }\end{array}$ & $\begin{array}{l}\text { Pleurosigma, } \\
\text { Amphora, } \\
\text { Guinardia, } \\
\text { Ditylum }\end{array}$ & - \\
\hline 4 & $\begin{array}{l}\text { Ditylum, } \\
\text { Odontella, } \\
\text { Chaetoceros }\end{array}$ & Navicula & $\begin{array}{l}\text { Rhizosolenia, } \\
\text { Nitzschia, } \\
\text { Skeletonema, } \\
\text { Protoperi- } \\
\text { dinium, } \\
\text { Peridinium }\end{array}$ \\
\hline 5 & $\begin{array}{l}\text { Thalassiosira, } \\
\text { Coscinodiscus }\end{array}$ & - & - \\
\hline 6 & $\begin{array}{l}\text { Navicula, } \\
\text { Coscinodiscus, } \\
\text { Peridinium, } \\
\text { Dinophysis }\end{array}$ & $\begin{array}{l}\text { Nitzschia, } \\
\text { Chaetoceros, } \\
\text { Pleurosigma, } \\
\text { Pseudo- } \\
\text { nitzschia, } \\
\text { Ditylum }\end{array}$ & - \\
\hline
\end{tabular}

\begin{tabular}{|c|c|c|c|}
\hline 7 & $\begin{array}{l}\text { Navicula, } \\
\text { Thalassiosira, } \\
\text { Cyclotella, } \\
\text { Ceratium, } \\
\text { Nitzschia, } \\
\text { Peridinium }\end{array}$ & - & - \\
\hline 8 & $\begin{array}{l}\text { Cyclotella, } \\
\text { Ceratium }\end{array}$ & $\begin{array}{l}\text { Coscinodiscus, } \\
\text { Navicula }\end{array}$ & - \\
\hline 9 & $\begin{array}{l}\text { Nitzschia, } \\
\text { Ceratium }\end{array}$ & $\begin{array}{l}\text { Skeletonema, } \\
\text { Cyclotella }\end{array}$ & - \\
\hline 10 & $\begin{array}{c}\text { Nitzschia, } \\
\text { Chaetoceros, } \\
\text { Navicula }\end{array}$ & $\begin{array}{c}\text { Ceratium, } \\
\text { Thalassionema }\end{array}$ & Thalassiosira \\
\hline 11 & $\begin{array}{l}\text { Cyclotella, } \\
\text { Skeletonema }\end{array}$ & Nitzschia & - \\
\hline 12 & Skeletonema & Navicula & - \\
\hline 13 & $\begin{array}{l}\text { Navicula, } \\
\text { Nitzschia, } \\
\text { Odontella }\end{array}$ & $\begin{array}{l}\text { Cyclotella, } \\
\text { Thalassiosira, } \\
\text { Bellerochea }\end{array}$ & - \\
\hline 14 & $\begin{array}{c}\text { Skeletonema, } \\
\text { Odontella }\end{array}$ & $\begin{array}{l}\text { Gyrosigma, } \\
\text { Guinardia }\end{array}$ & Nitzschia \\
\hline 15 & - & - & $\begin{array}{c}\text { Thalassiosira, } \\
\text { Bellerochea }\end{array}$ \\
\hline 16 & $\begin{array}{c}\text { Cyclotella, } \\
\text { Cerataulina, } \\
\text { Gyrosigma, } \\
\text { Chaetoceros, } \\
\text { Melosira, } \\
\text { Hemidiscus, } \\
\text { Bacillaria, } \\
\text { Bacteriastrum }\end{array}$ & Pleurosigma & - \\
\hline
\end{tabular}

TABLE 2: Continued.

\begin{tabular}{|c|c|c|c|}
\hline Weeks & Stn1 & $\operatorname{Stn} 2$ & $\operatorname{Stn} 3$ \\
\hline 17 & $\begin{array}{l}\text { Ceratium, } \\
\text { Chaetoceros, } \\
\text { Cyclotella, } \\
\text { Thalassiosira, } \\
\text { Actinocyclus }\end{array}$ & $\begin{array}{c}\text { Navicula, } \\
\text { Cylindrotheca }\end{array}$ & - \\
\hline 18 & $\begin{array}{l}\text { Chaetoceros, } \\
\text { Thalassiosira, } \\
\text { Cylindrotheca, } \\
\text { Hemidiscus }\end{array}$ & $\begin{array}{c}\text { Actinocyclus, } \\
\text { Odontella, } \\
\text { Navicula }\end{array}$ & - \\
\hline 19 & $\begin{array}{l}\text { Navicula, } \\
\text { Chaetoceros }\end{array}$ & $\begin{array}{l}\text { Pleurosigma, } \\
\text { Thalassionema, } \\
\text { Thalassiosira }\end{array}$ & - \\
\hline 20 & Nitzschia & $\begin{array}{c}\text { Thalassionema, } \\
\text { Gyrosigma, } \\
\text { Odontella }\end{array}$ & $\begin{array}{l}\text { Ceratium, } \\
\text { Noctiluca, } \\
\text { Cerataulina, } \\
\text { Cocconeis }\end{array}$ \\
\hline 21 & $\begin{array}{l}\text { Noctiluca, } \\
\text { Pleurosigma, } \\
\text { Cerataulina, } \\
\text { Planktoniella }\end{array}$ & Amphora & $\begin{array}{l}\text { Surirella, } \\
\text { Odontella, } \\
\text { Lauderia, } \\
\text { Chaetoceros, } \\
\text { Eucampia }\end{array}$ \\
\hline 22 & $\begin{array}{l}\text { Cyclotella, } \\
\text { Pleurosigma, } \\
\text { Ceratium, } \\
\text { Nitzschia, } \\
\text { Surirella }\end{array}$ & $\begin{array}{l}\text { Amphora, } \\
\text { Chaetoceros, } \\
\text { Cylindrotheca, } \\
\text { Pinnularia, } \\
\text { Amphiprora }\end{array}$ & - \\
\hline 23 & $\begin{array}{c}\text { Thalassionema, } \\
\text { Thalassiosira, } \\
\text { Pinnularia, } \\
\text { Paralia }\end{array}$ & $\begin{array}{l}\text { Triceratium, } \\
\text { Cymbella, } \\
\text { Amphiprora, } \\
\text { Peridinium }\end{array}$ & Surirella \\
\hline 24 & - & Melosira & $\begin{array}{c}\text { Surirella, } \\
\text { Amphiprora, } \\
\text { Pinnularia, } \\
\text { Thalassionema, } \\
\text { Climacosphe- } \\
\text { nia, } \\
\text { Ditylum }\end{array}$ \\
\hline 25 & $\begin{array}{c}\text { Amphora, } \\
\text { Amphipleura }\end{array}$ & $\begin{array}{l}\text { Ceratium, } \\
\text { Rhizosolenia }\end{array}$ & $\begin{array}{c}\text { Nitzschia, } \\
\text { Planktoniella, } \\
\text { Lauderia, } \\
\text { Skeletonema, } \\
\text { Phormidium, } \\
\text { Melosira }\end{array}$ \\
\hline 26 & $\begin{array}{c}\text { Ditylum, } \\
\text { Triceratium, } \\
\text { Peridinium, } \\
\text { Chaetoceros, } \\
\text { Cylindrotheca, } \\
\text { Ceratium, } \\
\text { Gyrosigma }\end{array}$ & - & $\begin{array}{l}\text { Cyclotella, } \\
\text { Surirella, } \\
\text { Cocconeis }\end{array}$ \\
\hline 27 & $\begin{array}{l}\text { Nitzschia, } \\
\text { Cocconeis, } \\
\text { Cyclotella }\end{array}$ & $\begin{array}{l}\text { Spirogyra, } \\
\text { Thalassiosira }\end{array}$ & $\begin{array}{c}\text { Oscillatoria, } \\
\text { Ceratium }\end{array}$ \\
\hline 28 & $\begin{array}{l}\text { Cylindrotheca, } \\
\text { Navicula }\end{array}$ & $\begin{array}{l}\text { Fragilaria, } \\
\text { Thalassiosira, } \\
\text { Phormidium, } \\
\text { Rhizosolenia, } \\
\text { Amphora, } \\
\text { Triceratium, } \\
\text { Cymbella }\end{array}$ & $\begin{array}{c}\text { Ceratium, } \\
\text { Gyrosigma, } \\
\text { Thalassionema }\end{array}$ \\
\hline
\end{tabular}


TABLE 2: Continued.

\begin{tabular}{lccc}
\hline Weeks & Stn1 & Stn2 & Stn3 \\
\hline 29 & Synechococcus & $\begin{array}{c}\text { Rhizosolenia, } \\
\text { Chaetoceros }\end{array}$ & Melosira \\
\hline \multirow{3}{*}{30} & $\begin{array}{c}\text { Thalassiothrix, } \\
\text { Raphidiopsis, } \\
\text { Amphiprora, } \\
\text { Pleurosigma }\end{array}$ & $\begin{array}{c}\text { Melosira, } \\
\text { Rhizosolenia }\end{array}$ & - \\
& Skeletonema, & Cyclotella, & \\
& Cylindrotheca, & Triceratium, & Melosira, \\
& Coscinodiscus, & Thalassiothrix, & Nitzschia \\
& Thalassionema & Minutocellus & \\
\hline
\end{tabular}

slowly reappeared into the ecosystem with the onset of winter and thereafter persisted in the weeks encompassing winter, spring, and summer across all the stations (17th-31st week).

Centric diatoms were more abundant across all the stations compared to pennate forms, except in 21st, 23rd, and 24 th weeks when pennate forms were high in abundance (mean abundance, $1.9 \times 10^{3}$ cells/L) with high generic diversity (14 genera).

Major diatom genera which were abundant (e.g., Coscinodiscus, Chaetoceros, Cyclotella, Thalassiosira, Navicula and Nitzschia) showed variation in their biovolume as part of this study. For example, Chaetoceros in winter showed a mean biovolume of $35281 \mu \mathrm{m}^{3}$ during the winter period (19th-21st week), while during spring and summer (23rd-31st week) the cells showed a mean biovolume of $9847 \mu \mathrm{m}^{3}$ (Table 3).

3.4. Nutrient Concentrations. There were characteristic shifts in dissolved nitrate concentration along seasonal scales. The mean nitrate concentration in Chemaguri creek was $85.4 \mu \mathrm{M}(\operatorname{Stn} 1=83.4 \mu \mathrm{M}$ and $\operatorname{Stn} 2=87.5 \mu \mathrm{M})$ and $54.2 \mu \mathrm{M}$ in the estuary (Stn3) (Figure 4). Concentration of dissolved (ortho)-phosphate demonstrated three clear peaks over the study period, the highest from 8th to 12th week (September-October, 2010), followed by 1st-3rd week (June-July, 2010) and also from 16th to 18th (December, 2010). On average, dissolved (ortho)phosphate concentration in the creek and estuarine system were recorded as $18.5 \mu \mathrm{M}$ (Stn1 $=17.5 \mu \mathrm{M}$ and $\operatorname{Stn} 2=19.4 \mu \mathrm{M})$ and $5.8 \mu \mathrm{M}(\operatorname{Stn} 3)$, respectively (Figure 4$)$.

Dissolved silicate concentration in the creek depicted an average of $85.77 \mu \mathrm{M}(\operatorname{Stn} 1=89.43 \mu \mathrm{M}$ and $\operatorname{Stn} 2=82.12 \mu \mathrm{M})$ while in the estuary (Stn3) it was only $61.33 \mu \mathrm{M}$ during the study period. Major peaks in the concentration of dissolved silicate (mean, $149.3 \mu \mathrm{M}$ in the creek, Stn1 and Stn2) were recorded during the 13th-21st week (November-February) while silicate concentration could not be detected from 21st to 23rd week (February-March, 2011) across the study sites (Figure 4).

3.5. Photosynthetic Pigments. Overall concentration of chlorophyll- $a$ in the creek was higher $9.36 \mathrm{mg} / \mathrm{m}^{3}$ (Stn1 = $11 \mathrm{mg} / \mathrm{m}^{3}$ and Stn $2=8 \mathrm{mg} / \mathrm{m}^{3}$ ) compared to the estuarine station (Stn3, mean $7.42 \mathrm{mg} / \mathrm{m}^{3}$ ). The Chlorophyll- $a$ data in the creek (Stn1 and Stn2) showed an increase from 1st to 4th week (June-July, 2010; mean, $45.85 \mathrm{mg} / \mathrm{m}^{3}$ ) of sampling. Thereafter, two minor peaks of Chlorophyll- $a$ were detected inside creek (Stn1 and Stn2) during the months of December, 2010 (16th-19th week) and May, 2011 (29th week) with an average concentration of $29 \mathrm{mg} / \mathrm{m}^{3}$ (Stn1 = $29.6 \mathrm{mg} / \mathrm{m}^{3}$ and $\operatorname{Stn} 2=28.3 \mathrm{mg} / \mathrm{m}^{3}$ ) and $6.3 \mathrm{mg} / \mathrm{m}^{3}$ $\left(\operatorname{Stn} 1=6.27 \mathrm{mg} / \mathrm{m}^{3}\right.$ and $\left.\operatorname{Stn} 2=6.49 \mathrm{mg} / \mathrm{m}^{3}\right)$ respectively (Figure 5).

Fucoxanthin, a pigment characteristic of phytoplankton groups such as Bacillariophyta, Dinophyta, Chrysophyta, Dictyophyta, and Pelagophyta, analyzed only at certain weeks of sampling, exhibited temporal shifts that corresponded with periods of significant changes in hydrological parameters in the water column (in the weeks encompassing the months of October-November, 2010 and February-April, 2011) (Figure 6). Average fucoxanthin concentration in the creek was $24.74 \mathrm{mg} / \mathrm{m}^{3}\left(\operatorname{Stn} 1=28.5 \mathrm{mg} / \mathrm{m}^{3}\right.$ and Stn $2=$ $21 \mathrm{mg} / \mathrm{m}^{3}$ ) while in the estuarine station (Stn3) it was $33.2 \mathrm{mg} / \mathrm{m}^{3}$.

3.6. rbcL Clone Library and Molecular Phylogenetics. Fiftytwo $r b c \mathrm{~L}$ clones were sequenced representing three time points for Stn 2 as part of this study. All the clones showed significant identity (92-100\%) with published cultured and uncultured eukaryotic $r b c \mathrm{~L}$ amino acid sequences based on blastp results. Sequences showing identity with major type ID chromophytic algal groups, namely, Bacillariophyta, Cryptophyta, Eustigmatophyta, Pelagophyta, and Haptophyta, were detected in the clone libraries. Majority of the $r b c \mathrm{~L}$ sequences (80\%) from clone libraries showed significant identities (95$100 \%$ ) with published $r b c \mathrm{~L}$ amino acid sequences representing cultured and uncultured diatoms (Bacillariophyta) based on blastp analysis as well as in molecular phylogenetic approach (see Figures S1A and B). The GC content of the sequenced $r b c \mathrm{~L}$ clones ranged between 37 and $44 \%$.

Ten clones were sequenced from the $r b c \mathrm{~L}$ clone library made from Stn2 environmental DNA of April 2010. Out of ten clones, one clone (Stn2_Apr10_clone1) showed $100 \%$ identity at the amino acid level with an uncultured eukaryotic $r b c \mathrm{~L}$ clone (Acc. ADB88913) sequenced previously from the coastal water of Monterey Bay, California whereas the lowest identity of $92 \%$ was recorded for another clone (Stn2_Apr10_clone7) with the $r b c \mathrm{~L}$ sequence of cultured pelagophyte Aureoumbra lagunensis (Acc. YP_003002090) at the amino acid level. Twelve clones were sequenced from the sample collected in December 2010 (19th week) from Stn2. Two clones (Stn2_Dec10_clone7 and Stn2_Dec10_clone11) showed $99 \%$ identity at the amino acid level with an uncultured marine microorganism $r b c \mathrm{~L}$ clone (Acc. ACS71707) sequenced previously from West Florida shelf of Gulf of Mexico. Lowest identity of 95\% was recorded for one clone (Stn2_Dec10_clone4) with the same sequence (Acc. ACS71707) targeted previously from Gulf of Mexico. Thirty $r b c \mathrm{~L}$ clones were sequenced from the sample collected in March, 2011 (24th week) from Stn2. Six clones (Stn2_Mar11_clone1, 3, 17, 23, 25 and 27) showed 100\% identity 
TABLE 3: Size class structure of dominant diatom genera based on biovolume estimation.

\begin{tabular}{|c|c|c|c|c|c|c|c|c|}
\hline \multicolumn{5}{|c|}{ 19-21 weeks (winter) } & \multicolumn{4}{|c|}{ 22-31 weeks (spring and summer) } \\
\hline Genera & $\begin{array}{c}\text { Cell } \\
\text { dimension } \\
(\mu \mathrm{m})\end{array}$ & $\begin{array}{l}\text { Biovolume } \\
\quad\left(\mu \mathrm{m}^{3}\right)\end{array}$ & $\begin{array}{c}\text { Mean } \\
\text { abundance } \\
\text { of } \\
\text { respective } \\
\text { genera }(/ \mathrm{L})\end{array}$ & $\begin{array}{c}\text { Mean } \\
\text { phytoplankton } \\
\text { cell abundance } \\
(/ \mathrm{L})\end{array}$ & $\begin{array}{c}\text { Cell } \\
\text { dimension } \\
(\mu \mathrm{m})\end{array}$ & $\begin{array}{l}\text { Biovolume } \\
\quad\left(\mu \mathrm{m}^{3}\right)\end{array}$ & $\begin{array}{c}\text { Mean } \\
\text { abundance } \\
\text { of } \\
\text { respective } \\
\text { genera }(/ \mathrm{L})\end{array}$ & $\begin{array}{c}\text { Mean } \\
\text { phytoplankton } \\
\text { cell } \\
\text { abundance } \\
(/ \mathrm{L})\end{array}$ \\
\hline Coscinodiscus & $204 ; 5$ & 226080 & 1500 & & $104 ; 4$ & 33962.24 & 880 & \\
\hline Chaetoceros & $106 ; 4$ & 35281.04 & 20 & & $56 ; 3$ & 9847.04 & 120 & \\
\hline Cyclotella & $48 ; 2$ & 3617.28 & 209 & & $21 ; 1.5$ & 519.28 & 55 & \\
\hline Thalassiosira & $200 ; 3$ & 94200 & 354 & 3300 & $86 ; 4.5$ & 26126.37 & 210 & 7056 \\
\hline Navicula & $21 ; 4 ; 8$ & 527.52 & 375 & & $18 ; 6 ; 5$ & 423.9 & 310 & \\
\hline Nitzschia & $16 ; 2.5 ; 4.5$ & 90 & 62 & & $13 ; 2 ; 4$ & 52 & 110 & \\
\hline
\end{tabular}

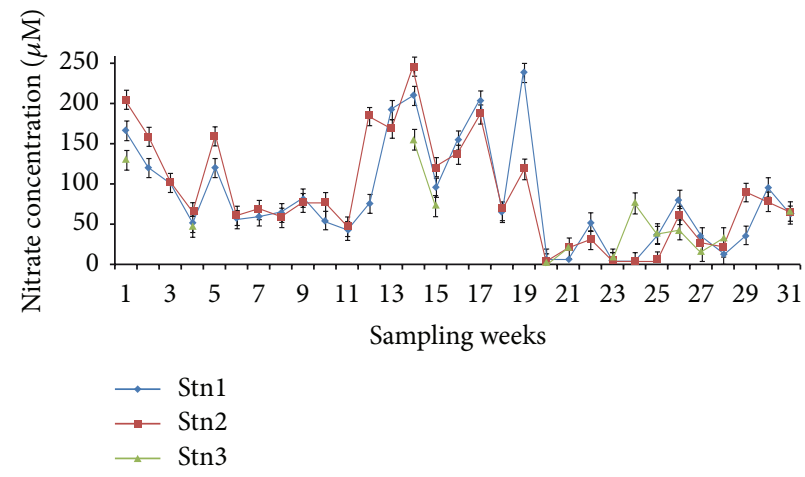

(a)

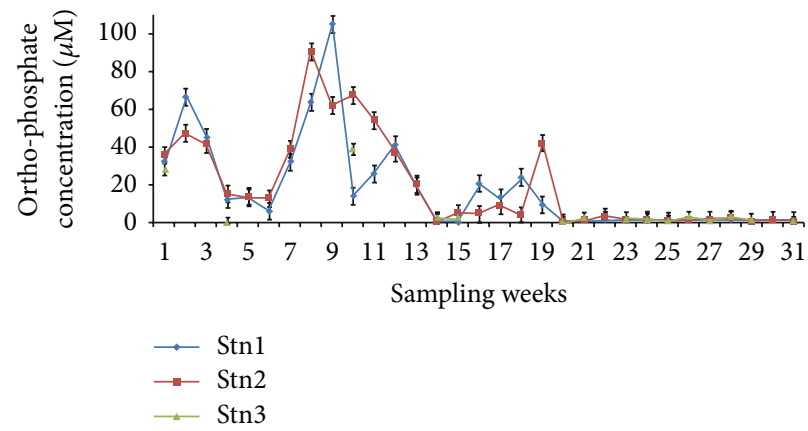

(b)

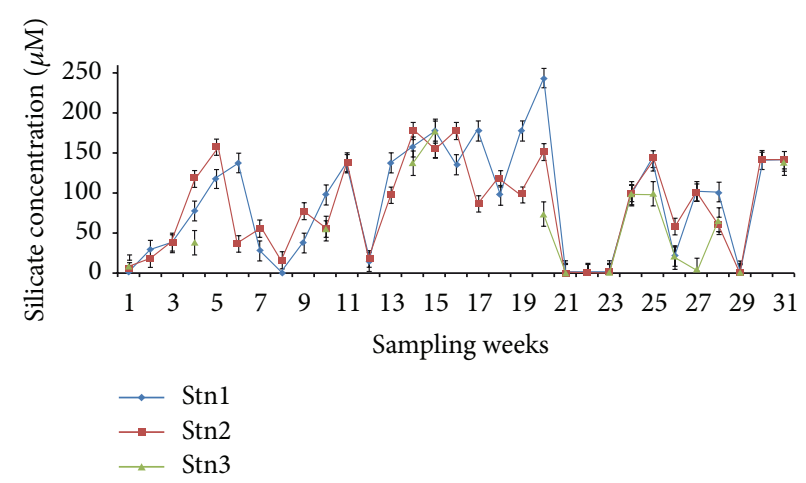

(c)

FIgure 4: Profile of (a) dissolved nitrate, (b) (ortho)-phosphate, and (c) silicate concentration across the study area.

at the amino acid level with $r b c \mathrm{~L}$ of an uncultured marine microorganism (Acc. ACS71707) sequenced previously from West Florida shelf in the Gulf of Mexico. Another clone (Stn2_Mar11_clone7) showed lowest identity of $96 \%$ to the same uncultured marine organism $r b c \mathrm{~L}$ sequence (Acc. ACS71707) from the Gulf of Mexico.

Phylogenetic approach based on Neighbor-Joining (NJ) method was undertaken to get a clearer understanding of the grouping of the $r b c \mathrm{~L}$ sequences generated from this study with published cultured and uncultured $r b c \mathrm{~L}$ sequences (see Figures S1A and B). Majority of the sequences generated in this study clustered with published uncultured and cultured $r b c \mathrm{~L}$ sequences belonging to Bacillariophyta (diatoms). The diatom cluster was the biggest group and showed strong bootstrap support. Thirteen sequences clustered with $r b c \mathrm{~L}$ sequences of several species of centric diatom Thalassiosira belonging to the order Thalassiosirales. Fourteen sequences also clustered with published $r b c \mathrm{~L}$ sequences of cultured diatom Minutocellus polymorphus and uncultured $r b c \mathrm{~L}$ sequences from Monterey Bay and Florida Shelf. Some sequences also clustered with members belonging to the orders Lithodesmiales, Bacillariales and Surirellales. 


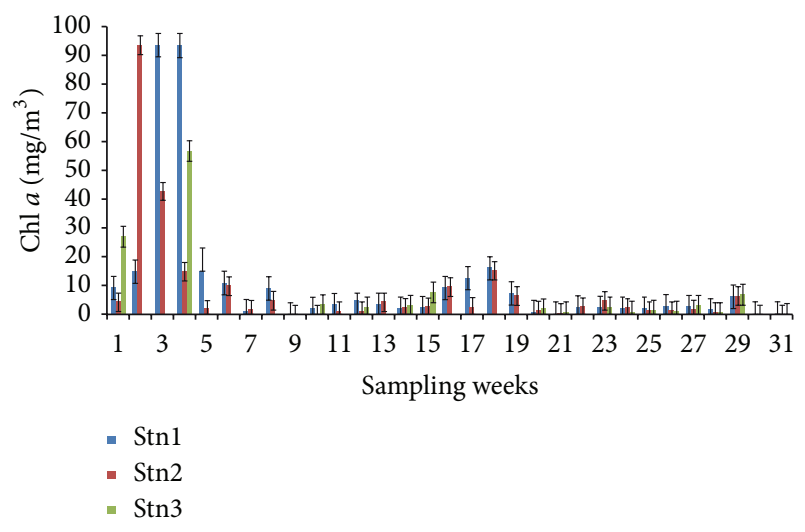

FIGURE 5: Profile of total chlorophyll- $a$ concentration over the study area.

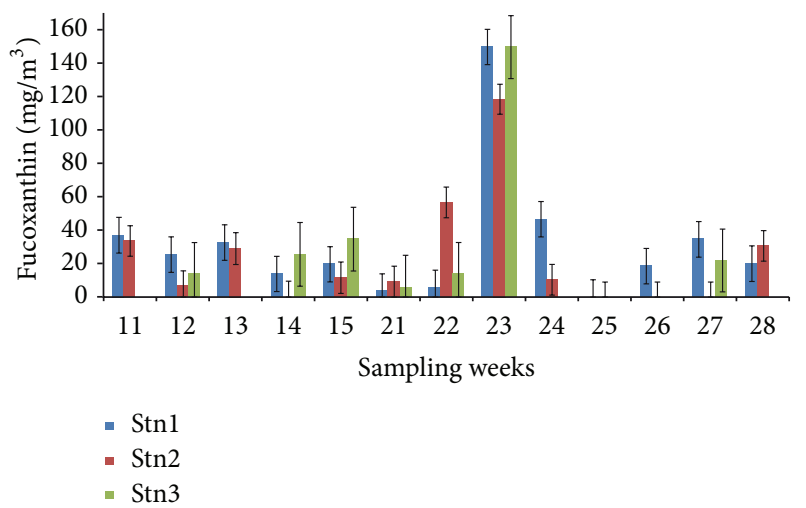

FIGURE 6: Shifting profile of total fucoxanthin concentration over the study area.

Five $r b c \mathrm{~L}$ sequences from the months of December (2010) and March (2011) clustered with published uncultured $r b c \mathrm{~L}$ sequences from Monterey Bay and cultured $r b c \mathrm{~L}$ sequence of Plagioselmis sp., Chroomonas sp. and other members belonging to Cryptophyta (see Figure S1A). Two sequences namely Stn2_Apr10_clone1 and Stn2_Apr10_clone8 clustered with $r b c \mathrm{~L}$ sequences of cultured members of Haptophyta namely Phaeocystis pouchetii and Platychrysis sp. Another $r b c \mathrm{~L}$ clone Stn2_Apr10_clone7 clustered with members of cultured Pelagophytes at the phylogeny level. A single clone Stn2_Dec10_clone5 showed phylogenetic affiliation with uncultured Eustigmatophyta like $r b c \mathrm{~L}$ sequences (see Figure S1A).

3.7. Statistical Analysis. In total, 20 OTUs were detected based on $3 \%$ cutoff value at the amino acid sequence level from the pooled $r b c \mathrm{~L}$ clone libraries of Stn2 from April 2010, December 2010, and March 2011 (Table 4). Highest number of OTUs (8) was recorded from both April 2010 and December 2010 clone libraries (Table 4). Lowest OTUs (7) was recorded from March 2011 although sequencing effort was not uniform across all the libraries (Table 4). Expected number of OTUs richness was calculated using nonparametric ChaoI estimator and the overall richness for all the clone libraries combined was 35.6. Highest ChaoI value (29) was recorded from April 2010 whereas lowest value (8.5) was recorded from March 2011 (see Table 4). The phylotype frequency curve based on pooled clone libraries showed that one OTU represented by 3,1 , and 12 sequences from April 2010, December 2010, and March 2011 clone libraries, respectively, was detected throughout the study period, while remaining 19 OTUs were detected only during certain time of the year. Among 20 OTUs, 12 OTUs represented the diatoms, whereas 8 OTUs belonged to nondiatom groups (Cryptophyta-4, Haptophyta-2, Pelagophyta1, and Eustigmatophyta-1). Shannon-Wiener diversity (H) indices calculated for all the $r b c \mathrm{~L}$ clone libraries have been detailed in Table 4 . The overall diversity $(\mathrm{H})$ was 2.35 . The $\mathrm{H}$ index was highest (1.973) for Stn2 December 2010 rbcL clone library (Table 4). Lowest $\mathrm{H}$ index (1.474) was recorded from March 2011 and this may have been due to limited sequencing efforts undertaken for this library. The rarefaction analysis was also undertaken to compare the relative OTUs richness among libraries targeted from three time points of Stn2. In case of April 2010 and December 2010 clone libraries, the rarefaction curves showed under saturation indicating clearly that the sequencing effort was not fully exhaustive (Figure S2). But for the March 2011 clone library the rarefaction curve tended towards saturation indicating sequencing effort was substantial compared to other libraries (Figure S2).

\section{Discussion}

The present study was undertaken to investigate temporal succession of phytoplankton assemblages ( $\geq 10 \mu \mathrm{m}$ size range and above) in the aquatic ecosystem of a macro-tidal mangrove creek (Chemaguri creek) and adjoining estuary (Mooriganga estuary) in the Sagar Island of Sundarbans mangroves. Additionally, for the first time molecular methods based on $r b c L$ approach were employed to detect the presence of phytoplankton groups lesser than $10 \mu \mathrm{m}$ size from this ecosystem.

Phytoplankton abundance, diversity, and their temporal trends in the creek and estuary were enumerated through conventional methods of microscopy and photosynthetic pigment analysis in link with measurement of hydrological parameters. We confirmed the overwhelming dominance of diatoms (Bacillariophyta) (40 genera) in phytoplankton assemblages from this part of the Sundarbans for the entire study period (June 2010-May 2011). Some of the dominant genera recorded in this study were identified to species level and they were Chaetoceros affinis (centric diatom), Coscinodiscus radiatus (centric diatom), Thalassiosira punctigera (centric diatom), Cyclotella stylorum (centric diatom), Nitzschia longissima (pennate diatom), and Navicula rhombica (pennate diatom). The dominance of several centric and pennate diatom genera throughout the study period, irrespective of the time of sampling, could be directly linked to their growth rates (divisions per day), and indirectly through interaction with environmental gradients [34].

Previous reports on phytoplankton diversity and assemblage patterns in the Sundarbans, based on local shortterm surveys, presented a broad picture of phytoplankton 
TABLE 4: Total number of clones sequenced, OTU distributions, diversity and richness estimates for all the $r b c \mathrm{~L}$ clone libraries from April 2010, December 2010 and March 2011 of Stn2.

\begin{tabular}{lccccc}
\hline Clone Library & $\begin{array}{c}\text { Number of } r b c \mathrm{~L} \\
\text { sequences }\end{array}$ & $\begin{array}{c}\text { OTU } \\
(>3 \%)\end{array}$ & $\begin{array}{c}\text { Shannon-Wiener } \\
\text { Index }(\mathrm{H})\end{array}$ & $\begin{array}{c}\text { Chao } \\
\text { (average) }\end{array}$ & $\begin{array}{c}\text { Abundance coverage } \\
\text { estimator (ACE) }\end{array}$ \\
\hline Total $r b c L$ sequences & 52 & 20 & 2.34 & 35.6 & 41.2727 \\
April_2010 & 10 & 8 & 1.973 & 29 & 44.8148 \\
December_2010 & 12 & 8 & 1.979 & 11.33 & 14.0482 \\
March_2011 & 30 & 7 & 1.474 & 8.5 & 12.449 \\
\hline
\end{tabular}

distribution across the ecoregion. For example, Banerjee and Santra [35] reported 48 species of diatoms from HooglyMatla estuarine system of the Sundarbans; Biswas et al. [36] documented the dominance of diatoms (36 genera) encompassing three sites off the northeast coast of the Bay of Bengal (off Mooriganga, Saptamukhi and Thakuran estuaries); Manna et al. [8] reported the occurrence of 46 phytoplankton genera with diatoms being the numerically dominant group (26 genera) from the Baro Herobhanga Khal (Jharkhali Island) in the Sundarbans. In all these studies, plankton net with $\geq 20 \mu \mathrm{m}$ mesh was used for sample collection and phytoplankton cells smaller than $20 \mu \mathrm{m}$ were missed out. They also found that euryhaline phytoplankton taxa were abundant in Sundarbans. Reports from other studies indicated the prevalence of phytoplankton groups (>20 $\mu \mathrm{m}$ ) across different mangrove environments [37, 38]. Unlike in the Sundarbans, the phytoplankton communities in tropical Matang mangrove creeks and estuarine systems in Malaysia were found to be dominated by members belonging to Dinophyta (80\% relative abundance) [39]. Phytoplankton assemblages in Bangladesh part of the Sundarbans, Indus delta (mangrove) creek system in Pakistan, Achara mangrove ecosystem along the west coast of India and mangroves adjoining Kaw estuary, French Guiana were found to be dominated by diatoms $[6,38,40,41]$, respectively. Overall, centric diatoms (21 genera) dominated in our collections across all the stations in Chemaguri creek of Sagar Island. Pennate diatoms, represented by 19 genera, were composed mainly of displaced benthic forms (7 genera) (especially in $\operatorname{Stn} 2)$.

In general, the centric forms (21 genera) constituted major part of the diatom assemblages in Chemaguri creek and Mooriganga river estuary throughout the study period. However, in the weeks encompassing February-March 2011 (21st-24th week), pennate diatoms representing 14 genera (including 6 benthic genera) were found to dominate diatom assemblages over centric forms (13 genera) across all the stations. Intense tidal mixing processes may have displaced benthic pennate diatom genera (e.g., Amphora, Navicula, and Surirella) and resulted in their abundance in the water column of Chemaguri creek. The latter group has lower settling rates than the centric forms, signifying the competitive advantage of pennate diatoms in phytoplankton assemblages [42]. It is therefore likely that these benthic diatoms are playing important role by augmenting primary production in this ecosystem at least during this period of the year. Several authors have emphasized on the importance of benthic diatoms in primary production in mangrove environments $[43,44]$. We also documented frequent occurrences of benthic (broken) filamentous cyanophyta (e.g., Phormidium sp.) in water samples collected in March (2011).

Higher abundances of phytoplankton ( $10 \mu \mathrm{m}$ and above) were documented in samples collected during the winter months (December, 2010 encompassing 25th-28th week; mean $1.2 \times 10^{4}$ cells/L in the creek encompassing Stn 1 and Stn2; sampling was not possible for Stn3 during this time due to logistic constraints). This coincided with low turbidity (mean, $30.5 \mathrm{~cm}$ secchi depth inside the creek Stn1 and Stn2), dissolved nutrient concentrations were high in the creek and hydrological parameters were relatively stable after months of turbulence and heavy precipitation in and around Sagar Island. Phytoplankton production in the mangrove aquatic systems of New Guinea (e.g., Fly delta and Purari delta) and Indonesia have been linked to turbidity in the water column [45] whereas in Australian mangroves, phytoplankton production were found to be correlated with dissolved inorganic phosphate concentration [46]. Importantly, large celled (e.g., Hemidiscus, Bacteriastrum) and long chain forming (e.g., Chaetoceros, Cerataulina) diatoms constituted the winter assemblage inside creek (Stn1 and Stn2). Zooplankton (e.g., copepods) abundance was higher (mean 250 ind./L inside the creek) in the weeks encompassing the spring (March) of 2011 which also coincided with the increase in abundance of small sized diatoms (mostly $10 \mu \mathrm{m}$ ) from the study area. The increase in zooplankton abundance indicated abundantavailability of food resources such as diatoms, to drive overall production in the study area.

Phytoplankton abundances were found to be lower during the monsoon period (7th-12th week; mean value of $7.96 \times$ $10^{2}$ cells/L in the creek encompassing Stn1 and Stn2; $1.4 \times$ $10^{3}$ cells/L in estuarine Stn3). This corresponded witha significantly lower salinity regimen (mean $2.6 \mathrm{ppt}$ in thecreek and $3.7 \mathrm{ppt}$ in the estuary) recorded from the studyarea, following heavy precipitation during monsoon of 2010.Salinity appears to be the factor that is strongly linked tolower phytoplankton abundances in creek and adjoiningestuary, but additional factors including temperature andlight may have contributed to this pattern, as also observed in studies which were focused on estuaries [47]. Several studies have also shown the link between salinity contour and phytoplankton abundance (e.g., Po River estuary, Italy [48], Kennebec estuary, Maine, USA [49], Pearl River estuary, China [50]). 
Heavy precipitation, though unusual, characterized the winter (February) of 2011 in Sagar Island. Although dissolved nutrients in the water column along with light intensities (as evident from secchi depth) were favorable, phytoplankton cell abundances were relatively lower during this period. This could be attributed to decrease in salinity which affected phytoplankton community structure and their overall abundance. The effect of decreasing salinity on phytoplankton cell abundance is well reported in the literature (e.g., [51]). Lately, however, in the month of March 2011, increase in cell abundance (in the 23rd-24th week; mean cell abundance at Stn $1=1.97 \times 10^{4}$ cells $/ \mathrm{L}$, Stn $2=1.25 \times 10^{4}$ cells $/ \mathrm{L}$ and Stn $3=5.9 \times 10^{3}$ cells $/ \mathrm{L}$ ) also coincided with persistent strong wind velocities. These observations were supported by the occurrence of abundant benthic pennate diatoms ( 6 genera) in our collections during this period of study. Interestingly, the centric diatoms in our spring collections were much smaller in size (e.g., Coscinodiscus with a size range of 51$157 \mu \mathrm{m}$ ) against their counterpart collected in winter (e.g., Coscinodiscus with a size range of $210-270 \mu \mathrm{m}$ ) from the study area. The size variations also corresponded with fluctuating nutrient conditions from the study area during winter of 2010 and spring of 2011, in particular for dissolved nitrate and ortho-phosphate. These observations were in agreement with previous studies that reported the presence of smaller sized phytoplankton cells under limiting nutrient conditions [5254].

Between 1st and 10th week, there was heavy precipitation over the study area. Strong winds blew mostly from southeast and southwest directions during this time of the study period. As illustrated by Mandal [55] the mean wind speed over the Sagar Island is around $19.5 \mathrm{Km} / \mathrm{h}$ in the months encompassing June-September. The conditions prevailed over the stations were unstable, reflected in the fluctuating profiles of hydrological parameters and nutrient concentrations across all the stations. During this time, phytoplankton assemblages across all the stations were dominated mostly by solitary (non-chain forming) taxa (e.g. Coscinodiscus, Cyclotella), capable of tolerating fluctuations in the prevailing hydrological parameters. Occurrences of these genera under variable hydrological conditions have been also reported in the literature [56].

Previous studies on phytoplankton assemblages in mangrove waters indicated relatively low abundance and diversity of phytoplankton taxa $[57,58]$. This situation was explained in relation to the release of tannins by decomposing mangrove parts [59].

Majority of the phytoplankton genera detected using microscopy were greater than $10 \mu \mathrm{m}$ in size (e.g., Tables 2 and 3) and showed temporal patterns including appearance/disappearance as discussed earlier. However, some of the genera including Minutocellus sp., Guinardia sp., and Surirella sp. which have cell size $\geq 10 \mu \mathrm{m}$ were found to constitute important components of the phytoplankton assemblage from the study sites thereby establishing the importance of $\geq 10 \mu \mathrm{m}$ sized algal communities from this environment.

As seen in this study, higher concentration of Chlorophyll- $a$ in the water samples from Chemaguri creek and Mooriganga estuary usually corresponded with higher cell abundance, with peaks in the months encompassing July 2010 (2nd-4th week; Stn $1=67.3 \mathrm{mg} / \mathrm{m}^{3}, \operatorname{Stn} 2=50.3 \mathrm{mg} / \mathrm{m}^{3}$ and Stn3 = $57 \mathrm{mg} / \mathrm{m}^{3}$ ), December 2010 (16th-18th week; Stn $\left.1=12.6 \mathrm{mg} / \mathrm{m}^{3} ; \mathrm{Stn} 2=9.14 \mathrm{mg} / \mathrm{m}^{3}\right)$ and May 2011 (29th week; Stn $1=6.27 \mathrm{mg} / \mathrm{m}^{3}, \operatorname{Stn} 2=6.49 \mathrm{mg} / \mathrm{m}^{3}$ and $\operatorname{Stn} 3=$ $6.93 \mathrm{mg} / \mathrm{m}^{3}$ ). Disparity between phytoplankton cell count and Chlorophyll- $a$ concentration was observed in some of the sampling weeks across all the stations as indicated earlier in the result. This was due tothe sample collection methodology. Samples collected formicroscopy involved $10 \mu \mathrm{m}$ mesh whereas samples collectedfor photosynthetic pigment analysis were captured in $0.45 \mu \mathrm{m}$ filter papers. Nevertheless, as we looked into the concentration of an accessory pigment, fucoxanthin indicative of some chromophytic algal groups including diatoms (11th-15th and 21st-28th week) showed higher values over chlorophyll- $a$ across all the stations. Shift in the concentration of fucoxanthin in water samples (from all the stations) matched well with that of shifts in phytoplankton cell abundance. It once again indicated towards the importance of diatoms and other chromophytic algal groups from this ecosystem. Increase in accessory photosynthetic pigment concentration over Chlorophyll- $a$ may have resulted from changed irradiances and photoadaptation in phytoplankton during those weeks of sampling as also reported in other studies $[60,61]$. Therefore the present study cautions in making generalized assumption that changes in pigment concentrations (Chlorophyll- $a$ and fucoxanthin, at least) will correspond with the changes in phytoplankton cell abundance, especially in highly turbid mangrove waters.

Concentrations of Chlorophyll- $a$ and fucoxanthin were well below their expected levels in comparison to phytoplankton cell abundance in the weeks encompassing AprilMay, 2011 (27th-31st week) across all the three stations. We used $10 \mu \mathrm{m}$ mesh plankton net for phytoplankton study and this may have missed out smaller sized cells and ultimately resulted in variation between photosynthetic pigments and phytoplankton cell abundance. It may be noted that the biomass collected for phytoplankton diversity analysis were concentrated using $10 \mu \mathrm{m}$ mesh phytoplankton net from $50 \mathrm{~L}$ of surface water, thereby the small sized phytoplankton cells may have been missed out during cell count, while $1 \mathrm{~L}$ of surface water (unconcentrated) was directly used for phytoplankton pigment analysis. The sampling methodology may have resulted in the observed variation between photosynthetic pigments and overall net phytoplankton cell abundance. Furthermore, the phytoplankton cells were generally smaller in size during this time of the sampling year (as described above) and we assume that a significant part of the diatom population from the study area was represented by senescent/dead cells as evident from the occurrence of empty diatom frustules in our collections across all the stations. Perhaps the dead cells were brought into suspension from the creek floor following continued wind action over the study area during this time of the year. It is therefore important to distinguish live from dead phytoplankton cells when undertaking ecological studies, as emphasized previously by Stevenson [62]. It should also be noted at this point 
that we have encountered few live (gliding by) but unpigmented (apochlorotic) diatom cells (mostly pennate, e.g., Navicula sp., Amphora sp.) from the creek (Stn1 and Stn2) in the weeks (27th-30th) encompassing April-May (2011). Those were mostly heterotrophic, ensuring survival under turbulence.

The relationship between primary production and phytoplankton biovolume has already been emphasized in the past [63]. The biovolume of dominant diatom taxa (e.g., Coscinodiscus, Chaetoceros, Cyclotella, Thalassiosira, Navicula and Nitzschia) from the study area showed significant changes from 19th-21st and 23rd-31st week which also corresponded with changes in hydrological and nutrient parameters during the same period (Table 3 ). Changes in biovolume were detected for major phytoplankton taxa from Sundarbans indicating major differences between years in size class composition [7].

Cryptophyta, although unidentified, were reported for the first time from Chemaguri creek system (Stn2). Identification of cryptophytes based on microscopy is extremely challenging, since they lack distinct discriminating morphological features. Moreover, they vary in cell shape or colour within a species. Therefore, classical identification of Cryptophytes is based on ultrastructural features and electron microscopy.

Cyanophyta were documented in high abundance during precipitation and post precipitation across all the stations in spring (2011) (e.g., Phormidium sp., Synechoccocus sp.). In the first week of August high abundances of Oscillatoria sp. were documented from the creek (Stn1 and Stn2; mean, 750 filaments/L).

Higher abundance of dinophyta like Noctiluca sp. (mean abundance, 625 cells/L) in the weeks encompassing February of 2011 (21st-22nd week) after the "Ganga-Sagar" event, pointed towards the poor water quality in creek and adjoining estuary. The results imply that local anthropogenic inputs were also responsible in controlling the community composition of phytoplankton in Sundarbans.

In a previous short-term study, we found that phytoplankton communities in the Chemaguri creek and adjacent Mooriganga estuary were driven by fluctuations in the concentration of three major dissolved nutrients [nitrate, (ortho)-phosphate, and silicate]. Therefore, the present study was intended to track the temporal succession of phytoplankton assemblages in link with shifts in concentration of dissolved nitrate, (ortho)-phosphate, and silicate.

Nutrient concentrations from our study showed some variability when compared with previous studies from other regions in the Sundarbans. For example, dissolved nitrate concentration in our study sites was $85.4 \mu \mathrm{M}$ (in creek) while a recent study from the Sundarbans reported sum of nitrate and nitrite concentration from $12.25 \pm 7.29 \mu \mathrm{M}$ [7]. Silicate (mean $85.7 \mu \mathrm{M}$ ) and phosphate values $(18.5 \mu \mathrm{M})$ measured during our study was significantly different than previously reported values $($ silicate $=46.3 \pm 18.32 \mu \mathrm{M}$, phosphate $=$ $0.68 \pm 0.46 \mu \mathrm{M}$ ) [7]. The observed high concentration of nitrate is caused by continuous runoff of fertilizers from aquaculture farms and agriculture lands located adjacent to the creek stations that flow through the creek and ultimately fall into the estuary. Dissolved nitrate concentration was shown to vary between 8 and $19 \mu \mathrm{M}$ in some sectors of the Sundarbans ecoregion where there were no significant inputs of nitrogen from anthropogenic sources [7]. But, a recent study from this region has shown that nitrate concentration can reach up to $35 \mu \mathrm{M}$ and this was attributed to occassional anthropogenic nitrogen inputs in the study site [64]. The silicate concentration (mean $85.7 \mu \mathrm{M}$ ) measured during our study was comparable with other studies where silicate concentration was found to vary between 35 and $77 \mu \mathrm{M}$ in Sundarbans [7]. In our study, mean phosphate concentration was found to be $18.5 \mu \mathrm{M}$ and this was caused due to an apparent increase in mean concentration from 7 th to 12 th week $(48 \mu \mathrm{M})$ of the study period. However, in other weeks the mean phosphate concentration $(8 \mu \mathrm{M})$ was similar to other studies focused on this ecoregion [7, 64]. The high concentration of these nutrients was indicative of outwelling of silicate and phosphate from the mangroves or from partdecomposed mangrove litters as observed in other mangrove environments such as Matang in Malaysia [39].

The $r b c \mathrm{~L}$ clone libraries for one of the creek stations (Stn2) was undertaken to detect smaller size phytoplankton (lesser than $10 \mu \mathrm{m}$ ) in the assemblages. The results obtained from $r b c \mathrm{~L}$ clone libraries were generally consistent with microscopic observations. Majority of the sequences in the clone libraries were diatom-like as also observed in case of microscopy, where bulk of the assemblages were found to be dominated by diatoms. Diatom genera like Cyclotella, Minutocellus, and Thalassiosira identified using microscopy were also detected in the $r b c \mathrm{~L}$ clone libraries. Small sized diatom like Thalassiosira minima and Campylodiscus clypeus, a diatom with high morphological variation, which are usually difficult to identify under a microscope, were detected in the $r b c \mathrm{~L}$ clone libraries indicating the importance of this methodological approach for studying phytoplankton assemblages from the study area. This also highlighted the drawback associated with plankton net for studying phytoplankton diversity in any ecosystem.

Besides diatoms, $r b c \mathrm{~L}$ sequences generated in this study also clustered with $r b c \mathrm{~L}$ sequences of other phytoplankton genera belonging to Cryptophyta (e.g., Chroomonas sp. Acc. AAM62089), Haptophyta (e.g., Isochrysis galbana, Acc. BAB20783; Phaeocystis pouchetii, Acc. BAF80671), Pelagophyta, and Eustigmatophyta as evident from the phylogenetic tree. For example, Cryptophyte-like $r b c \mathrm{~L}$ sequences were detected in the libraries of December 2010 and March 2011 for Stn2 but not in April 2010, and Haptophyte-like sequences were detected only in April 2010 Stn2 library. Although, sequencing efforts were limited, nevertheless a temporal pattern (seasonal scale) of phytoplankton community assemblages started to emerge from our study. It is therefore clear that the creek system, though dominated by diatoms like $r b c \mathrm{~L}$ sequences, also supports diverse phytoplankton functional groups of lesser than $10 \mu \mathrm{m}$ sizes. Phytoplankton diversity studies undertaken in different ecoregions based on $r b c \mathrm{~L}$ gene sequencing approach have provided interesting insights of 
assemblage structure and pattern $[15,16]$. Detection of Haptophyte and Pelagophyte-like $r b c \mathrm{~L}$ sequences from the clone libraries is the first report of its kind from the Sundarbans mangroves and indicates the importance of small sized algal cells in primary production.

While molecular signatures of groups such as Cryptophytes, Haptophytes, Pelagophytes, and Eustigmatophytes were detected in clone libraries, the representative genera of same groups except an unidentified Cryptophyte could not be detected based on microscopy as these groups usually represent small sized algal cells (lesser than $10 \mu \mathrm{m}$ ) which were not retained in plankton net at the time of sampling. This again highlighted the need to apply molecular techniques and also to limit the use of plankton net when elucidating phytoplankton assemblages from any environment.

Many of the $r b c \mathrm{~L}$ sequences from our clone libraries showed $93-100 \%$ identity at the amino acid level with uncultured eukaryotic $r b c \mathrm{~L}$ sequences targeted previously from the Gulf of Mexico and the Monterey Bay upwelling system in California indicating ubiquitous distribution of phytoplankton communities along large ecological gradients.

Interestingly, two clones (Stn2_Dec10_clonel and Stn2_ Dec10_clone3) amplified using the type ID $r b c \mathrm{~L}$ primers showed $98 \%$ and $99 \%$ identities with the $r b c \mathrm{~L}$ sequence of cultured dinophyte Dinophysis fortii (Acc BAD42428) based on blastp validation but clustered with the $r b c \mathrm{~L}$ of cryptophyte Teleaulax sp. in the phylogenetic tree; this observation has been already reported in published literature $[16,65]$. As part of the molecular phylogeny studies many new $r b c \mathrm{~L}$ sequences were detected from the creek (see Figures S1A and B), but the extent to which they represent novel types cannot be determined until greater effort is made to sequence the existing culture collections.

Similarly, when the GC contents of the sequenced clones were analyzed it was found that non-diatom $r b c L$ clones (e.g., Stn2_Apr10_clone8, Stn2_Dec10_clone3), which were confirmed additionally based on molecular phylogenetics and blastp validation, had significantly higher GC content ( $40 \%$ and above) compared to diatom $r b c \mathrm{~L}$ clones (less than $40 \%$ ). This warrants further investigation as also indicated in a recent study, where GC content in some diatom genes was found to be low in comparison to other chromophytic algal groups [66].

While sequencing effort was very preliminary for all the clone libraries, nevertheless 20 OTUs were detected from Stn2 for three time points and many of these OTUs corresponded with 49 genera detected from the same station based on microscopy. However with preliminary sequencing effort, several OTUs representing ciliates, nanoflagellates and picoeukaryotic groups such as Cryptophyta, Haptophyta, Pelagophyta, and Eustigmatophyta were detected in $r b c \mathrm{~L}$ libraries highlighting their importance in this ecosystem.

Additionally $r b c \mathrm{~L}$ signatures of many non-diatom genera such as Phaeocystis and Plagioselmis were detected for the first time in Sundarbans which has not been reported in previous studies based entirely on microscopy. Therefore, this study clearly show that an approach based on microscopy and molecular methods can significantly improve our understanding of the phytoplankton community structure.

It is evident from this study (when compared with the previous reports from different sites of the Sundarbans) that the creek ecosystems in the Sundarbans are driven by intrinsic local factors controlling distribution and dynamics of biota. This study has shown that hydrological parameters in the water column of the creek and adjoining estuary play important role in controlling the succession of phytoplankton assemblages $(10 \mu \mathrm{m}$ size and bigger). The $r b c \mathrm{~L}$ clonelibrary approach which was undertaken for the first time in Sundarbans highlights the presence of several cosmopolitan and novel phytoplankton lineages, in addition to presence of smaller cell sized non-diatom groups such as ciliates and nanoflagellates. Additionally the application of plankton net along with their mesh sizes should be taken into consideration when studying biodiversity from mangrove environments. Overall this study highlights the necessity of integrating different approaches including molecular methods for a better understanding of phytoplankton community structure in mangrove environments including the Sundarbans.

\section{Authors' Contribution}

Dola Bhattacharjee and Brajogopal Samanta contributed equally to this work.

\section{Acknowledgments}

This work is supported by grants awarded to Punyasloke Bhadury from WWF-India and IISER-K. Brajogopal Samanta is the recipient of an IISERK Ph.D. Fellowship. The authors are grateful to the boat crew for assistance with field sampling activities.

\section{References}

[1] R. E. C. Mantoura, J. M. Martin, and R. Wollast, Ocean Margin Processes in Global Change, John Wiley \& Sons, Chichester, UK, 1991.

[2] C. Giri, E. Ochieng, L. L. Tieszen et al., "Status and distribution of mangrove forests of the world using earth observation satellite data," Global Ecology and Biogeography, vol. 20, no. 1, pp. 154-159, 2011.

[3] A. I. Robertson and S. Blaber, "Plankton, epibenthos and fish communities," in Tropical Mangrove Ecosystems, A. I. Robertson and D. M. Alongi, Eds., American Geophysical Union, Washington, DC, USA, 1992.

[4] M. Spalding, F. Blasco, and F. Field, World Mangrove Atlas, The International Society for Mangrove Ecosystems, Okinawa, Japan, 1997.

[5] P. Bhadury, "Planktons," in Environmental Management and Biodiversity Conservation Plan For Sundarbans Biodiversity: State of the Report, A. K. Ghosh, Ed., WWF-India and World Bank, 2013.

[6] M. M. Mamun, M. G. Sarower, M. A. Ali, S. M. B. Rahman, and K. A. Huq, "Abundance and distribution of plankton in the Sundarbans mangrove Forest," Journal of Innovation and Development Strategy, vol. 3, no. 3, pp. 43-54, 2009. 
[7] H. Biswas, M. Dey, D. Ganguly, T. K. De, S. Ghosh, and T. K. Jana, "Comparative analysis of phytoplankton composition and abundance over a two-decade period at the land-ocean boundary of a tropical mangrove ecosystem," Estuaries and Coasts, vol. 33, no. 2, pp. 384-394, 2010.

[8] S. Manna, K. Chaudhuri, S. Bhattacharyya, and M. Bhattacharyya, "Dynamics of Sundarban estuarine ecosystem: eutrophication induced threat to mangroves," Saline Systems, vol. 6, no. 1, article 8, 2010.

[9] S. B. Saha, S. B. Bhattacharyya, and A. Choudhury, "Photosynthetic activity in relation to hydrobiological characteristics of a brackishwater tidal ecosystem of Sundarbans in West Bengal, India," Tropical Ecology, vol. 42, no. 1, pp. 111-115, 2001.

[10] R. Massana, J. Castresana, V. Balagué et al., "Phylogenetic and ecological analysis of novel marine stramenopiles," Applied and Environmental Microbiology, vol. 70, no. 6, pp. 3528-3534, 2004.

[11] N. J. Fuller, C. Campbell, D. J. Allen et al., "Analysis of photosynthetic picoeukaryote diversity at open ocean sites in the Arabian Sea using a PCR biased towards marine algal plastids," Aquatic Microbial Ecology, vol. 43, no. 1, pp. 79-93, 2006.

[12] F. R. Tabita, "Microbial ribulose 1,5-bisphosphate carboxylase/ oxygenase: a different perspective," Photosynthesis Research, vol. 60 , no. 1, pp. 1-28, 1999.

[13] G. M. F. Watson and F. R. Tabita, "Regulation, unique gene organization, and unusual primary structure of carbon fixation genes from a marine phycoerythrin-containing cyanobacterium," Plant Molecular Biology, vol. 32, no. 6, pp. 1103-1115, 1996.

[14] J. H. Paul, A. Alfreider, and B. Wawrik, "Micro- and macrodiversity in rbcL sequences in ambient phytoplankton populations from the southeastern Gulf of Mexico," Marine Ecology Progress Series, vol. 198, pp. 9-18, 2000.

[15] B. Wawrik, J. H. Paul, L. Campbell et al., "Vertical structure of the phytoplankton community associated with a coastal plume in the Gulf of Mexico," Marine Ecology Progress Series, vol. 251, pp. 87-101, 2003.

[16] P. Bhadury and B. B. Ward, "Molecular diversity of marine phytoplankton communities based on key functional genes," Journal of Phycology, vol. 45, no. 6, pp. 1335-1347, 2009.

[17] K. N. Mukherjee, "Nature and problems of neoreclamation in the Sundarbans," Indian Journal of Landscape Systems and Ecological Studies, vol. 6, pp. 1-19, 1983.

[18] X. L. Verlencar and S. Desai, Phytoplankton Identification Manual, NIO, Goa, India, 2004.

[19] R. Subrahmanyan, "A systematic account of the marine plankton diatoms of the Madras coast," Proceedings of the Indian Academy of Sciences B, vol. 24, no. 4, pp. 85-197, 1946.

[20] T. V. Desikachary, Cyanophyta, Indian Council of Agricultural Research, New Delhi, India, 1959.

[21] T. V. Desikachary, Atlas of Diatoms, Monographs fasicle II, III and IV, Madras Science Foundation, Madras, India, 1987.

[22] H. Hillebrand, C.-D. Dürselen, D. Kirschtel, U. Pollingher, and T. Zohary, "Biovolume calculation for pelagic and benthic microalgae," Journal of Phycology, vol. 35, no. 2, pp. 403-424, 1999.

[23] D. Bhattacharjee, B. Samanta, A. Danda, and P. Bhadury, "Understanding the impact of climate change in the Sundarbans aquatic ecosystem-phytoplankton as proxies," in Climate Change and Island and Coastal Vulnerability, J. Sundaresan, S. Sreekesh, A. Ramanathan, L. Sonnenschein, and R. Boojih, Eds., pp. 126-140, Springer, 2013.
[24] M. S. Finch, D. J. Hydes, C. H. Clayson, B. Weigl, J. Dakin, and P. Gwilliam, "A low power ultra violet spectrophotometer for measurement of nitrate in seawater: introduction, calibration and initial sea trials," Analytica Chimica Acta, vol. 377, no. 2-3, pp. 167-177, 1998.

[25] J. D. H. Strickland and T. R. Parsons, A Practical Handbook of Seawater Analysis, Fisheries Research Board of Canada, Ottawa, Canada, 1972.

[26] R. E. Turner, N. Qureshi, N. N. Rabalais et al., "Fluctuating silicate:nitrate ratios and coastal plankton food webs," Proceedings of the National Academy of Sciences of the United States of America, vol. 95, no. 22, pp. 13048-13051, 1998.

[27] C. J. Lorenzen, "A method for the continuous measurement of in vivo chlorophyll concentration," Deep-Sea Research and Oceanographic Abstracts, vol. 13, no. 2, pp. 223-227, 1966.

[28] K. H. Boström, K. Simu, Å. Hagström, and L. Riemann, “Optimization of DNA extraction for quantitative marine bacterioplankton community analysis," Limnology and Oceanography: Methods, vol. 2, pp. 365-373, 2004.

[29] B. Wawrik, J. H. Paul, and F. R. Tabita, "Real-time PCR quantification of $r b c \mathrm{~L}$ (ribulose-1,5-bisphosphate carboxylase/oxygenase) mRNA in diatoms and pelagophytes," Applied and Environmental Microbiology, vol. 68, no. 8, pp. 3771-3779, 2002.

[30] N. Saitou and M. Nei, “The neighbor-joining method: a new method for reconstructing phylogenetic trees," Molecular Biology and Evolution, vol. 4, no. 4, pp. 406-425, 1987.

[31] K. Tamura, D. Peterson, N. Peterson, G. Stecher, M. Nei, and S. Kumar, "MEGA5: molecular evolutionary genetics analysis using maximum likelihood, evolutionary distance, and maximum parsimony methods," Molecular Biology and Evolution, vol. 29, no. 2, pp. 457-472, 2011.

[32] J. Felsenstein, "Confidence limits on phylogenies: an approach using the bootstrap," Evolution, vol. 39, no. 4, pp. 783-791, 1985.

[33] P. D. Schloss and J. Handelsman, "Introducing DOTUR, a computer program for defining operational taxonomic units and estimating species richness," Applied and Environmental Microbiology, vol. 71, no. 3, pp. 1501-1506, 2005.

[34] T. U. Chan and D. P. Hamilton, "Effect of freshwater flow on the succession and biomass of phytoplankton in a seasonal estuary," Marine and Freshwater Research, vol. 52, no. 6, pp. 869-884, 2001.

[35] A. Banerjee and S. C. Santra, "Plankton population and population density of the Sundarbans mangrove estuary of West Bengal (India)," in Sundarbans Mangal, D. N. Guha Bakshi, P. Sanyal, and K. R. Naskar, Eds., Naya Prokash, Calcutta, India, 1999.

[36] H. Biswas, S. K. Mukhopadhyay, T. K. De, S. Sen, and T. K. Jana, "Biogenic controls on the air-water carbon dioxide exchange in the Sundarban mangrove environment, northeast coast of Bay of Bengal, India," Limnology and Oceanography, vol. 49, no. 1, pp. 95-101, 2004.

[37] P. E. Campbell, J. A. Manning, M. K. Webber, and D. F. Webber, "Planktonic communities as indicators of water quality in mangrove lagoons; a Jamaican case study," Transitional Waters Bulletin, vol. 3, pp. 39-63, 2008.

[38] P. J. Harrison, N. Khan, K. Yin et al., "Nutrient and phytoplankton dynamics in two mangrove tidal creeks of the Indus River delta, Pakistan," Marine Ecology Progress Series, vol. 157, pp. 1319, 1997. 
[39] K. Tanaka and P.-S. Choo, "Influences of nutrient outwelling from the Mangrove swamp on the distribution of phytoplankton in the Matang Mangrove Estuary, Malaysia," Journal of Oceanography, vol. 56, no. 1, pp. 69-78, 2000.

[40] V. V. Dham, M. Wafar, and A. M. Heredia, "Nitrogen uptake by size-fractionated phytoplankton in mangrove waters," Aquatic Microbial Ecology, vol. 41, no. 3, pp. 281-291, 2005.

[41] F. Sylvestre, D. Guiral, and J. P. Debenay, "Modern diatom distribution in mangrove swamps from the Kaw Estuary (French Guiana)," Marine Geology, vol. 208, no. 2-4, pp. 281-293, 2004.

[42] P. K. Bienfang and P. J. Harrison, "Sinking-rate response of natural assemblages of temperate and subtropical phytoplankton to nutrient depletion," Marine Biology, vol. 83, no. 3, pp. 293-300, 1984.

[43] L. A. Deegan and R. H. Garritt, "Evidence for spatial variability in estuarine food webs," Marine Ecology Progress Series, vol. 147, no. 1-3, pp. 31-47, 1997.

[44] H.-L. Hsieh, C.-P. Chen, Y.-G. Chen, and H.-H. Yang, "Diversity of benthic organic matter flows through polychaetes and crabs in a mangrove estuary: $\delta 13 \mathrm{C}$ and $\delta 34 \mathrm{~S}$ signals," Marine Ecology Progress Series, vol. 227, pp. 145-155, 2002.

[45] S. Soe-modihardjo, "Indonesia," in Technical Report of the UNDP/UNESCO Research and Training Pilot Programme on Mangrove Ecosystems in Asia and the Pacific, R. M. Umali, P. M. Zamora, R. R. Gotera, R. S. Jara, A. S. Kamacho, and M. Vannucci, Eds., Natural Resources Management Centre and National Mangrove Committee, Ministry of Natural Resources, Manila, Philippines, 1987.

[46] D. M. Alongi, K. G. Boto, and A. I. Robertson, "Nitrogen and phosphorus cycles," in Tropical Mangrove Ecosystems, A. I. Robertson and D. M. Alongi, Eds., pp. 251-292, American Geophysical Union, Washington, DC, USA, 1992.

[47] E. L. Quinlan and E. J. Phlips, "Phytoplankton assemblages across the marine to low-salinity transition zone in a blackwater dominated estuary," Journal of Plankton Research, vol. 29, no. 5, pp. 401-416, 2007.

[48] N. Revelante and M. Gilmartin, "The effect of Po river discharge on phytoplankton dynamics in the Northern Adriatic Sea," Marine Biology, vol. 34, no. 3, pp. 259-271, 1976.

[49] M. W. Wong and D. W. Townsend, "Phytoplankton and hydrography of the Kennebec estuary, Maine, USA," Marine Ecology Progress Series, vol. 178, pp. 133-144, 1999.

[50] K. Yin, P.-Y. Qian, J. C. Chen, D. P. H. Hsieh, and P. J. Harrison, "Dynamics of nutrients and phytoplankton biomass in the Pearl River estuary and adjacent waters of Hong Kong during summer: preliminary evidence for phosphorus and silicon limitation," Marine Ecology Progress Series, vol. 194, pp. 295-305, 2000.

[51] N. A. Aizdaicher and Z. V. Markina, "The effect of decrease in salinity on the dynamics of abundance and the cell size of Corethron hystrix (Bacillariophyta) in laboratory culture," Ocean Science Journal, vol. 45, no. 1, pp. 1-5, 2010.

[52] K. G. Porter, "The plant-animal interface in freshwater ecosystems," American Scientist, vol. 65, pp. 159-170, 1977.

[53] R. Margalef, "Life forms of phytoplankton as survival alternatives in an unstable environment," Oceanologica Acta, vol. 1, no. 4, pp. 493-509, 1978.

[54] R. E. H. Smith and J. Kalff, "Competition for phosphorus among co-occurring freshwater phytoplankton," Limnology and Oceanography, vol. 28, no. 3, pp. 448-464, 1983.

[55] A. K. Mandal, The Sundarbans of India: A Development Analysis, Indus Publishing Company, New Delhi, India, 2003.
[56] J. O. Olomukoro and C. Oronsaye, "The plankton studies of the gulf of Guinea, Nigeria," Bioscience Research Communications, vol. 21, pp. 71-75, 2009.

[57] M. B. Kutner, "Seasonal variation and phytoplankton distribution in Cananeia region, Brazil," in Proceedings of the International Symposium on the Biology and Management of Mangroves, G. E. Walsh, S. C. Snedaker, and H. J. Teas, Eds., pp. 153-169, University of Florida, Honolulu, Hawaii, USA, 1975.

[58] M. Ricard, "Primary production in mangrove lagoon waters," in Hydrobiology of the Mangal, F. D. Por and I. Dor, Eds., Dr. W Junk Publishers, Hague, The Netherlands, 1984.

[59] J. Tundisi, T. M. Tundisi, and M. B. Kutner, "Plankton studies in a mangrove environment. VIII. Further investigations on primary production, standing-stock of phyto- and zooplankton and some environmental factors," International Review of Hydrobiology, vol. 58, no. 6, pp. 925-940, 1973.

[60] G. B. McManus, "Phytoplankton abundance and pigment changes during simulated in situ dilution experiments in estuarine waters: possible artifacts caused by algal light adaptation," Journal of Plankton Research, vol. 17, no. 8, pp. 1705-1716, 1995.

[61] E. Valenzuela-Espinoza, R. Millan-Nunez, C. C. Trees, E. Santamaria-del-Angel, and F. Nunez-Cebrero, "Growth and accessory pigments to chlorophyll a ratios of Thalassiosira pseudonana (Bacillariophyceae) cultured under different irradiances," Hydrobiologia, vol. 17, no. 3, pp. 249-255, 2007.

[62] R. J. Stevenson, "Epilithic and epipelic diatoms in the Sandusky River, with emphasis on species diversity and water pollution," Hydrobiologia, vol. 114, no. 3, pp. 161-175, 1984.

[63] D. L. Tison and E. W. Wilde, "Primary production and biovolume of various phototrophic plankton size fraction in three southeastern United States reservoirs," Applied and Environmental Microbiology, vol. 41, no. 4, pp. 1055-1059, 1981.

[64] K. Chaudhuri, S. Manna, K. S. Sarma, P. Naskar, S. Bhattacharyya, and M. Bhattacharyya, "Physicochemical and biological factors controlling water column metabolism in Sundarbans estuary, India," Aquatic Biosystems, vol. 8, no. 26, pp. 1-6, 2012.

[65] Y. Takahashi, K. Takishita, K. Koike et al., "Development of molecular probes for Dinophysis (Dinophyceae) plastid: a tool to predict blooming and explore plastid origin," Marine Biotechnology, vol. 7, no. 2, pp. 95-103, 2005.

[66] P. Bhadury, B. Song, and B. B. Ward, "Intron features of key functional genes mediating nitrogen metabolism in marine phytoplankton," Marine Genomics, vol. 4, no. 3, pp. 207-213, 2011. 

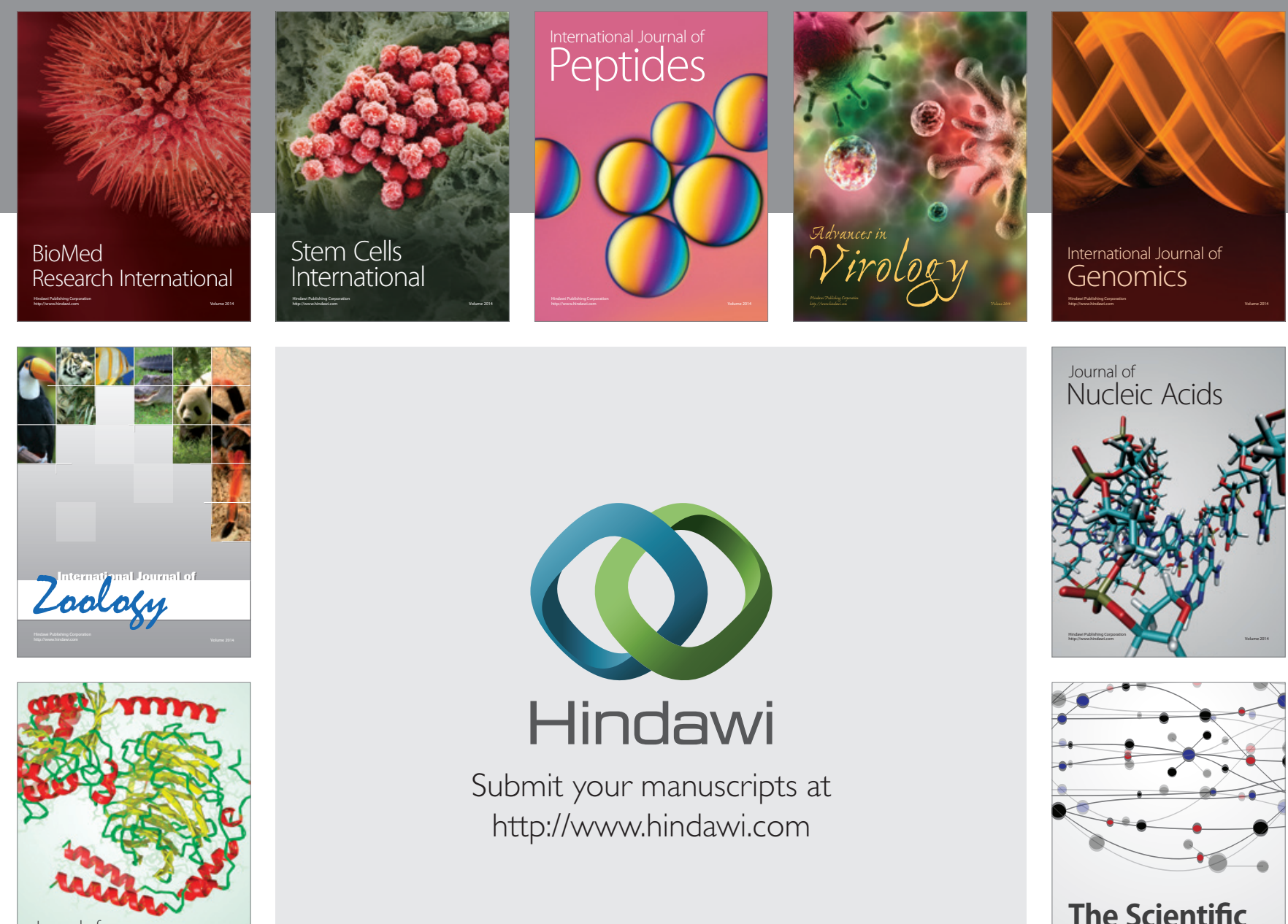

Submit your manuscripts at

http://www.hindawi.com

Journal of
Signal Transduction
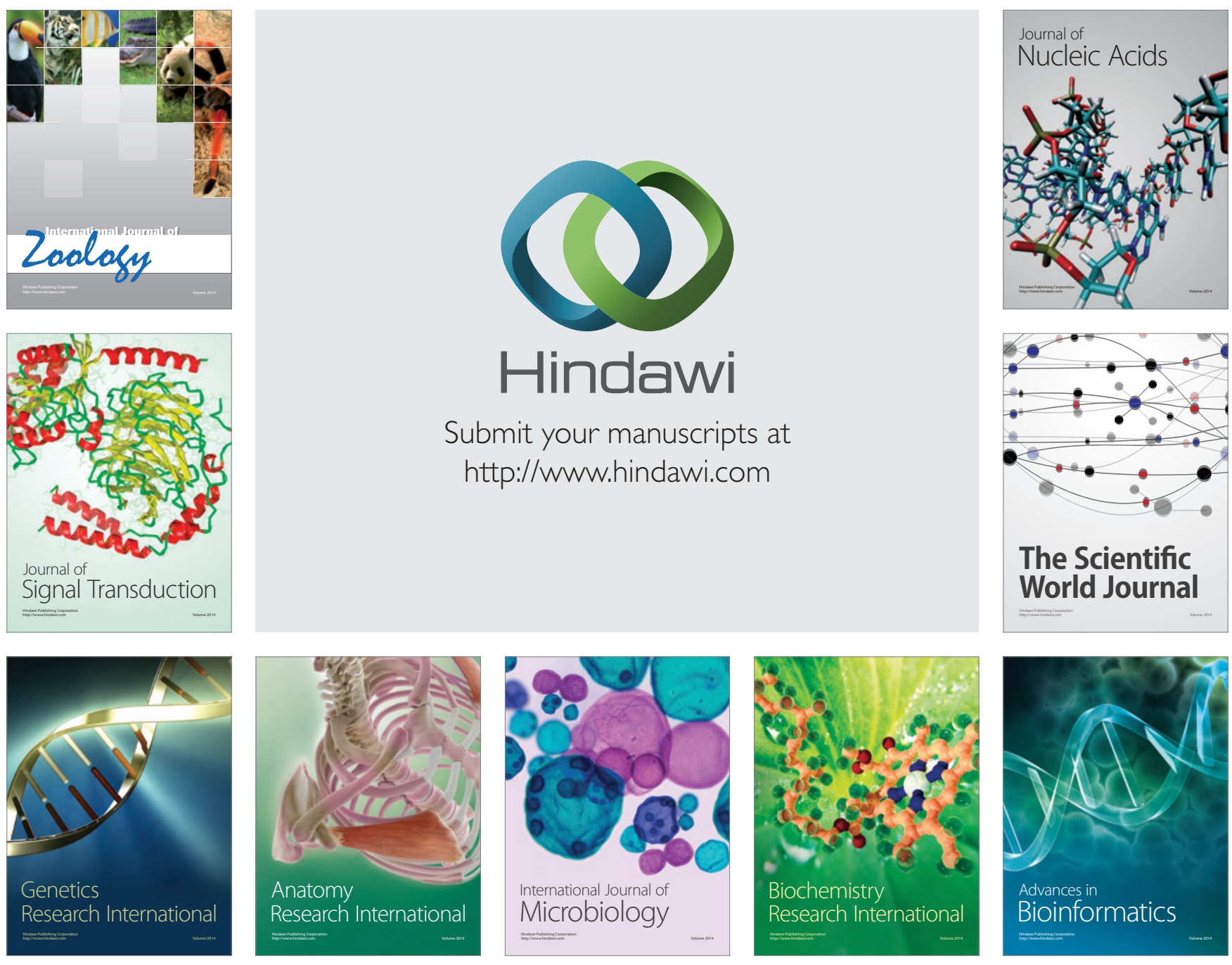

The Scientific World Journal
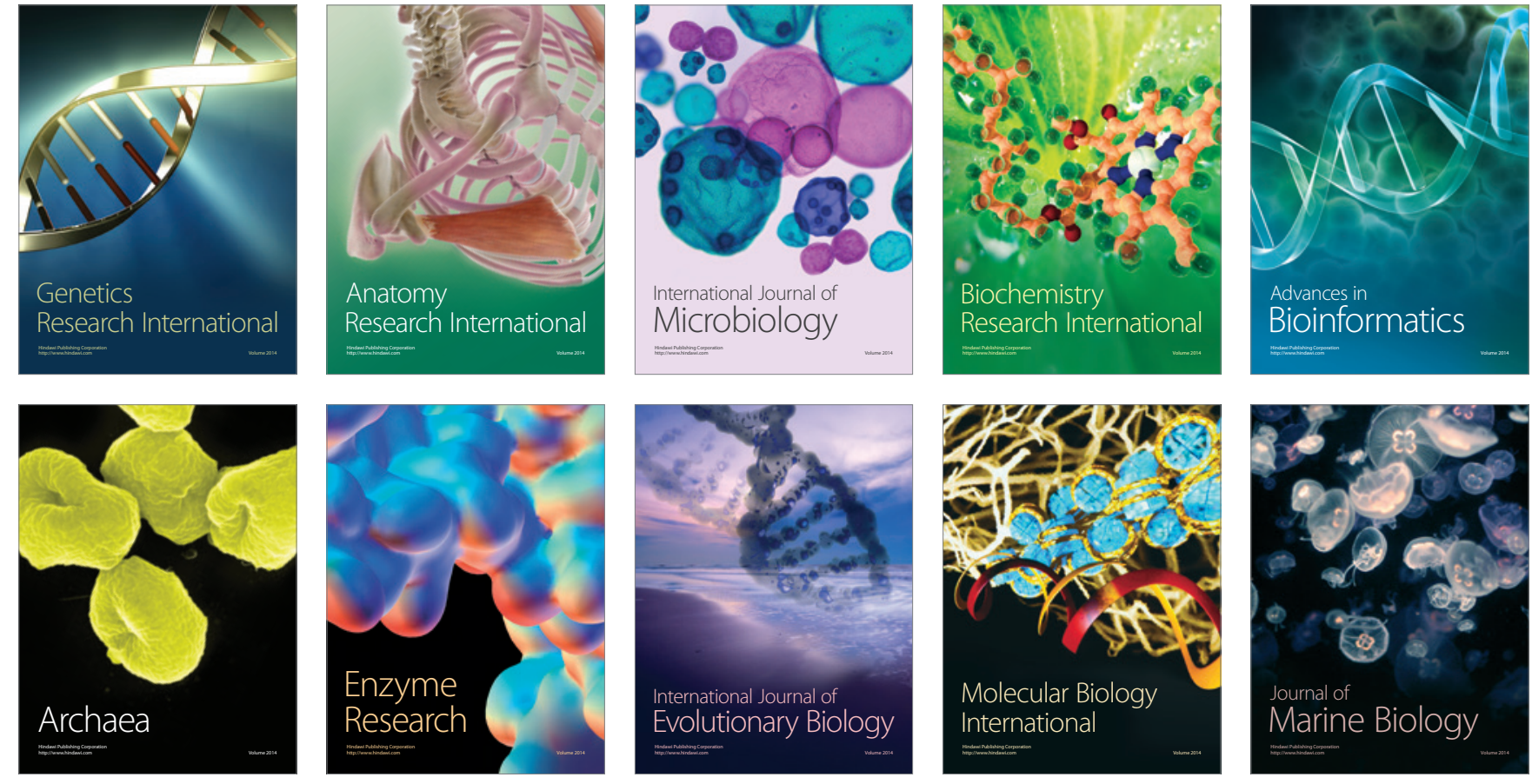